\title{
Evolution, immunity and the emergence of brain
}

\section{superautoantigens [version 1; peer review: 3 approved]}

\author{
Serge NatafiD
}

Bank of Tissues and Cells, Lyon University Hospital (Hospices Civils de Lyon), CarMeN Laboratory, INSERM 1060, INRA 1397, INSA Lyon, Université Claude Bernard Lyon-1, Lyon, F-69000, France

V1 First published: 21 Feb 2017, 6:171

https://doi.org/10.12688/f1000research.10950.1

Latest published: 21 Feb 2017, 6:171

https://doi.org/10.12688/f1000research.10950.1

\section{Abstract}

While some autoimmune disorders remain extremely rare, others largely predominate the epidemiology of human autoimmunity. Notably, these include psoriasis, diabetes, vitiligo, thyroiditis, rheumatoid arthritis and multiple sclerosis. Thus, despite the quasiinfinite number of "self" antigens that could theoretically trigger autoimmune responses, only a limited set of antigens, referred here as superautoantigens, induce pathogenic adaptive responses. Several lines of evidence reviewed in this paper indicate that, irrespective of the targeted organ (e.g. thyroid, pancreas, joints, brain or skin), a significant proportion of superautoantigens are highly expressed in the synaptic compartment of the central nervous system (CNS). Such an observation applies notably for GAD65, AchR, ribonucleoproteins, heat shock proteins, collagen IV, laminin, tyrosine hydroxylase and the acetylcholinesterase domain of thyroglobulin. It is also argued that cognitive alterations have been described in a number of autoimmune disorders, including psoriasis, rheumatoid arthritis, lupus, Crohn's disease and autoimmune thyroiditis. Finally, the present paper points out that a great majority of the "incidental" autoimmune conditions notably triggered by neoplasms, vaccinations or microbial infections are targeting the synaptic or myelin compartments. On this basis, the concept of an immunological homunculus, proposed by Irun Cohen more than 25 years ago, is extended here in a model where physiological autoimmunity against brain superautoantigens confers both: i) a crucial evolutionary-determined advantage via cognitionpromoting autoimmunity; and ii) a major evolutionary-determined vulnerability, leading to the emergence of autoimmune disorders in Homo sapiens. Moreover, in this theoretical framework, the so called co-development/co-evolution model, both the development (at the scale of an individual) and evolution (at the scale of species) of the antibody and T-cell repertoires are coupled to those of the neural repertoires (i.e. the distinct neuronal populations and synaptic circuits supporting cognitive and sensorimotor functions). Clinical implications and future experimental insights are also presented and discussed.
Open Peer Review

$\begin{array}{lccc}\text { Approval Status } & 2 & 3 \\ \text { version 1 } & 1 & & \\ 21 \text { Feb 2017 } & \text { view } & \text { view } & \text { view }\end{array}$

1. Irun R. Cohen (iD), Weizmann Institute of

Science, Rehovot, Israel

2. Abdelhadi Saoudi ID, INSERM (French Institute of Health and Medical Research), Toulouse, France

3. Carmen Guaza, Cajal Institute, CSIC, Madrid, Spain

Any reports and responses or comments on the article can be found at the end of the article. 


\section{Keywords}

autoantigens, immune repertoire, natural autoantibodies, immunological homunculus, synapse, paraneoplastic syndrome, autoimmunity, central nervous system

Corresponding author: Serge Nataf (serge.nataf@inserm.fr)

Competing interests: No competing interests were disclosed.

Grant information: The author(s) declared that no grants were involved in supporting this work.

Copyright: @ 2017 Nataf S. This is an open access article distributed under the terms of the Creative Commons Attribution License, which permits unrestricted use, distribution, and reproduction in any medium, provided the original work is properly cited. Data associated with the article are available under the terms of the Creative Commons Zero "No rights reserved" data waiver (CC0 1.0 Public domain dedication).

How to cite this article: Nataf S. Evolution, immunity and the emergence of brain superautoantigens [version 1; peer review: 3 approved] F1000Research 2017, 6:171 https://doi.org/10.12688/f1000research.10950.1

First published: 21 Feb 2017, 6:171 https://doi.org/10.12688/f1000research.10950.1 


\section{Introduction}

The role of auto-immune mechanisms in a large array of diseases continues to be extensively explored, and the identification of new target autoantigens is still an active field of research. However, despite the quasi-infinite number of potential target autoantigens that bear human cells, the majority of our internal antigenic library somehow remains off-target. Indeed, while many orphan autoimmune diseases have been described, the landscape of human autoimmunity is dominated by a limited number of disorders that include psoriasis, diabetes, vitiligo, thyroiditis, rheumatoid arthritis and multiple sclerosis. Moreover, besides "idiopathic" autoimmunity, for which no causative event can be conclusively identified, it is worth noting that "incidental" autoimmunity, triggered by neoplasms (paraneoplastic syndromes), vaccination (autoimmune/autoinflammatory syndrome induced by adjuvants [ASIA] $)^{1}$ or microbial infections (post-streptococcal glomerulonephritis and Guillain-Barre syndrome secondary to Campylobacter jejuni infection), does not affect all tissues and organs with an evenly distributed incidence. The great majority of such incidental autoimmune disorders clinically express as neurological pathologies and mainly target myelinic or neuronal autoantigens. Overall, these observations indicate that, independently from the MHC haplotype of an individual, autoantigens are not equal with regard to their potential for autoimmunity. There are what could be called superautoantigens, and in particular neural superautoantigens, toward which TCR and antibody repertoires tend to be skewed in humans.

It is proposed here that the existence of such superautoantigens is shaped by physiological events that are associated with human brain development and functions. The theory of the immunological homunculus, proposed more than 25 years ago by Irun Cohen ${ }^{2,3}$, constitutes an ideal framework to explain the emergence of superautoantigens during evolution. The present paper firstly provides a brief description of the somatosensory homunculus, i.e. the brain cortical area that, by analogy-based reasoning, inspired the concept of the immunological homunculus. Secondly, the immune and nervous systems are paralleled with regard to: i) the importance of self-generated inputs in the development of both somatosensory and immunological homunculi; and ii) the mechanisms driving a distorted representation of our body in both homunculi.

\section{The somatosensory homunculus provides a distorted representation of our body}

The somatosensory homunculus (Figure 1) essentially relates to the sense of touch and neural connections that are established between i) innervated skin territories where peripheral receptors for touch sensory inputs are located and ii) specific subareas of the brain cortex where neurons that integrate touch sensory input are located. The higher the density of sensory receptors in a given skin territory, the larger the surface covered by the corresponding cortical subarea ${ }^{4,5}$. As a consequence, depending on their respective densities in sensory receptors, two skin territories covering quantitatively similar surfaces may be connected to cortical areas covering greatly different surfaces. In this anatomical and functional segmentation, so-called somatotopy, the topographical heterogeneity of skin territories with regard to the density of sensory receptors is responsible for a distortion of our body representation in the sensory cortex. For example, skin terminal nerves located in the thumb are connected to a much larger brain cortical area than the terminal nerves innervating the whole trunk skin (Figure 1). From a functional point of view, this organization makes sense, since skin sensitivity needs to be highly efficient in anatomical territories requiring a finely tuned motor control, such as thumb, index, lips or tongue. Indeed, the acquisition of motor skills relies on bidirectional sensorimotor connections that allow motor and sensory activities to mutually fuel and integrate. The perception of our own motor activity, a process called sensory reafference (or sensory feedback), greatly participates in sculpting and refining motor programs $s^{6,7}$. Accordingly, in non-human primates, sensory loss in infancy profoundly alters the functional organization of the motor cortex ${ }^{8}$. Conversely, specific motor programs that are, in part, evolutionary-determined, instruct the use-dependent development of specific subareas of the sensory cortex. Principally, this was shown in experiments where sensory reafferences driven by early primitive motor activity were found to model the sensory cortex of rodents ${ }^{9}$. Finally, such feedback/ feedforward processes between sensory and motor neuronal networks also operate in conditions of post-developmental motor learning $^{10-12}$.

The somatosensory homunculus is initially shaped by selfgenerated sensory inputs

For neuroscientists, the term "developmental plasticity" mainly refers to the generation of nascent neuronal networks, which during brain development recruit additional neurons and acquire a higher order of intra- and/or inter-network connectivity ${ }^{13,14}$. In this specific field of research, the visual cortex has offered a unique experimental paradigm to analyze the impact of sensory inputs on the development of sensory neuronal networks. Thus, in cats, rodents and non-human primates, deprivation of visual inputs during early life stages hampers the formation of a fully functional neuronal circuitry in the visual cortex ${ }^{15-17}$. In addition, recent studies performed in congenitally blind $v s$ sighted humans demonstrated that both the functionality and connectivity of the visual cortex are, in part, shaped by visual experience ${ }^{18}$. Finally, such an experience-dependent development of sensory neuronal networks was also demonstrated in the somatosensory cortex: trimming the whiskers of newborn rodents induces a partial deprivation of touch sensory inputs that is accompanied by profound developmental alterations of the somatosensory cortex ${ }^{19-21}$.

Importantly, it was demonstrated that sensory experience impacts on developmental plasticity during specific windows of time, so-called critical periods ${ }^{22,23}$, which vary depending on the sensory input considered. Moreover, besides the existence of critical periods defined by specific time frames of brain development, it is acknowledged that experience-dependent plasticity actually persists in the adult sensory cortices, although to a lower magnitude ${ }^{24,25}$. The most illustrative example is given by the cortical reorganization of somatosensory neurons that follows hand amputation in adults ${ }^{26,27}$. 


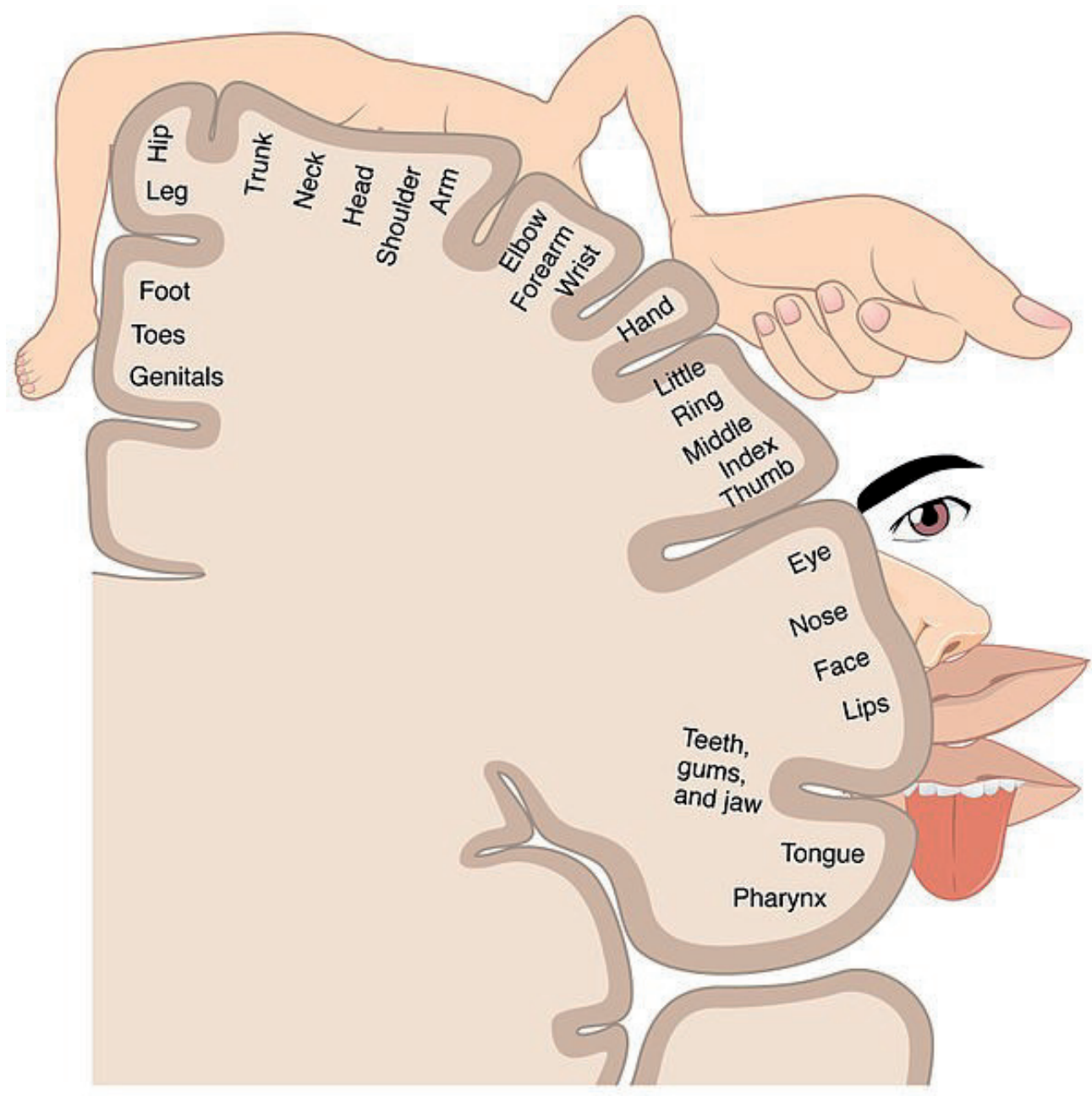

Figure 1. Representation of the somatosensory homunculus. The higher the density of sensory receptors in a given skin territory, the larger the surface covered by the corresponding cortical subarea that integrates inputs from this skin territory. In this anatomical and functional segmentation so-called somatotopy, the topographical heterogeneity of skin territories with regard to the density of sensory receptors is responsible for a distortion of our body representation in the sensory cortex. Thus, skin terminal nerves located in the thumb, lips or tongue are connected to a much larger brain cortical area than the terminal nerves innervating the whole trunk skin. The figure was obtained from Human Anatomy and Physiology, Chapter 14.2: Central Processing. OpenStax, Anatomy \& Physiology. OpenStax CNX. Jul 30, 2014 (http://cnx.org/contents/FPtK1zmh@6.27:KcreJ7oj@5/Central-Processing).

Recent findings show that in addition to exogenous inputs, selfgenerated inputs shape the somatosensory homunculus. In particular, as mentioned earlier, our own motor actions, conscious or unconscious, are a constant source of self-generated sensory inputs that reinforce the sensory neural circuitry. Thus, twitches, especially frequent in newborns during sleep, trigger robust sensory reafference that shape the sensory cortex ${ }^{28}$. Moreover, twitches are not randomly generated and have been proposed to provide a sensorimotor experience that helps build motor synergies for goaldirected wake movements, such as walking ${ }^{29,30}$. Lastly, that human fetuses perform synchronous and coordinated hand/mouth movements despite general motor immaturity ${ }^{31}$ is thought to reflect an evolutionary-determined imprinting of such a motor behavior ${ }^{31}$. In this regard, one may consider that nascent motor programs, which will ultimately support the achievement of species-specific motor behaviors (e.g. hand grasping, complex language-related oral motor skills and walking), provide a whole of self-generated sensory inputs that shape a distorted somatosensory homunculus. Overall, the distorted perception of our own body complementary relies on both experience-dependent and experience-independent (i.e innate) mechanisms that, in turn, are indispensable to the effective development and refinement of major human-specific motor programs.

The immunological homunculus provides molecular support to physiological autoimmunity

The term "immunological homunculus" and the associated notion of physiological autoimmunity refers to the development of adaptive immune responses directed against self-generated inputs i.e. "self" antigens ${ }^{2,3,32}$. Strikingly, human newborns harbor 
a non-maternally derived $\operatorname{IgM}$ repertoire that is directed toward autoantigens ${ }^{33-35}$. Given the sterile fetal environment, natural autoantibodies in newborns cannot result from mechanisms of cross-reactivity or molecular mimicry between "non-self" microbial antigens and "self" antigens. Interestingly, such a self-directed antibody repertoire has been proposed to form what could be called a "stem repertoire" from which networks of reactive and crossreactive antibodies are progressively generated ${ }^{35-38}$. In the same manner, the frequency of $\mathrm{T}$ cell receptors (TCRs) recognizing autoantigens is much more than predicted by the clonal selection theory. Indeed, the negative selection of auto-reactive T-cells via AutoImmune REgulator gene (AIRE)-dependent epithelial expression of autoantigens is far from constituting a stringent process. An abundance of molecular and cellular interactions that do not relate to clonal deletion prevent physiologically-generated auto-reactive T-cells to exert pathogenic effects ${ }^{39-41}$. Moreover, in-depth analysis of public TCRs (i.e. TCRs that are shared by a large population of individuals in a given species) has shown that "self" peptides are frequently recognized by such public TCRs and could even be their main targets ${ }^{42,43}$. Thus, there is now compelling evidence that, as initially proposed by Irun Cohen, physiological autoimmunity does not only reflect incidental errors of the selection/ tolerance immune machinery, but fulfills major functions under normal or pathological conditions. Notably, these include two major functions: i) anti-tumoral immune responses targeted toward developmentally-expressed autoantigens, which are re-expressed during the tumoral process ${ }^{33,44}$; and ii) support to cognition via the finely-tuned intra-central nervous system (CNS) activation of T-cells directed against brain antigens ${ }^{45-48}$. In addition, physiological autoimmunity against a specific set of "self" antigens may also prevent pathological autoimmunity against a distinct set of autoantigens. This was recently demonstrated in patients bearing AIRE mutations and exhibiting at the same time immune selfreactivity, responsible for pathological autoimmunity, and immune self-reactivity, protecting from pathological autoimmunity ${ }^{49}$. Finally, another unexpected advantage conferred by physiological autoimmunity is to provide extended immune repertoires directed against "non-self" antigens. In point of fact, TCRs or antibodies directed against "self" antigens cross-react with a large range of "non-self" antigens, and physiological autoimmunity is essential for successfully tackling microbial infections. In particular, T-cell clones endowed with high reactivity against "self" antigens are major components of the adaptive immune response against infectious agents ${ }^{50-52}$. Thus, overall, the assumption that acquisition of an immunological homunculus represents a major educational step of the immune system development is now largely confirmed.

The immunological homunculus is shaped by a limited set of superautoantigens, toward which adaptive immune responses confer an evolutionary advantage

An important conclusion that needs to be drawn from the concept of immunological homunculus is that autoimmunity is by essence a physiological process that is required for the harmonious maintenance of our tissues and the fine adaptation of the human species to its environment. Accordingly, physiological autoimmune responses against superautoantigens should provide an evolutionary advantage to the human species. Indeed, when providing a distorted representation of our body, the somatosensory homunculus skews the focus of our perceptive competencies toward skin territories that are essential to the execution of major motor functions in humans, for example walking upright, hand grasping and speech. Similarly, one may propose that the immunological homunculus skews the focus of "self"-directed adaptive immunity toward a specific set of autoantigens that, in humans, represent functionally important targets of physiological autoimmunity. Logically, in humans and other species endowed with a developed neo-cortex (the brain area supporting cognitive functions, arising from the most recent evolutionary changes), brainderived autoantigens should represent a major share of such a set of superautoantigens. Supporting this view, physiological mechanisms of cognition-promoting autoimmunity have been now extensively demonstrated in rodents. In particular, myelinspecific T-cell clones were shown to robustly stimulate neurogenesis in vivo via the synthesis of neurotrophic factors that are captured in situ by neural progenitors ${ }^{53,54}$. Conversely, T-cell deficient mice harbor profound cognitive alterations that can be reversed by adoptive transfer of CD4+ T-cells ${ }^{55,56}$. Interestingly, the cognition-promoting activity of T-cells was shown to specifically rely on a sub-population of memory $\mathrm{T}$-cells recognizing brainderived antigens and exhibiting homing properties toward meninges, choroid plexus and cervical lymph nodes (i.e. the regional lymph nodes draining cerebrospinal fluid) $)^{48,57,58}$.

Most importantly, the notion of physiological autoimmunity suggests that pathological autoimmunity may not result from the de novo emergence of pathogenic autoreactive clones, but from pre-existing autoreactive clones that have acquired abnormal functional properties ${ }^{2,44,59}$. In this regard, pathogenic autoimmunity and physiological autoimmunity should be expected to share the same preferential targets i.e. superautoantigens. Exposed below are several lines of evidence indicating that a major source of superautoantigens, targeted by both physiological and pathological autoimmunity, is provided by the CNS.

\section{The CNS is a major source of superautoantigens} Antigenic compartments formed by myelin and synapses exhibit specific immunogenic properties

There are two categories of properties that confer a high immunogenic potential to myelin-derived and synapse-derived antigens:

1) Abundance and high renewal rate: While abundance (amount of antigen) is an important factor that determines our immune system's ability to see and react against an antigen, the renewal rate of an antigen is likely to be at least as important. In most cases, renewal implies degradation by the phagocytic system, which is an indispensable step to antigen presentation by mononuclear phagocytes. Conversely, a highly abundant antigen that is poorly renewed may be predicted to be poorly immunogenic. In this view, two categories of brain antigens fulfills the criteria of being both abundant and highly renewed: synapse-derived and myelin-derived antigens. Indeed, synapses are highly dynamic structures that are constantly submitted to a remodeling process supporting the generation and maintenance of operative and adapted neuronal networks. Neurons represent roughly half of all CNS cells and, depending on the brain area considered, each human neuron bears $\sim 100,000$ synaptic connections (as inferred from electron microscopy analyses of cortical 
samples $)^{60}$. In addition, the synaptic circuitry in humans is highly plastic until at least the third decade, which translates into a high rate of both de novo formation and elimination of synapses ${ }^{61}$. Similarly, myelin (as assessed by measures of white matter volume) occupies nearly $25 \%$ of the total human brain volume ${ }^{62}$ and was recently shown to be renewed at a very high rate in the steady state ${ }^{63}$.

2) Inflammation-associated development and function: Microglial cells, brain-resident macrophages, play key regulatory functions during brain development and are currently considered as the main "architects" of nascent neuronal circuits ${ }^{64}$. Such a unique function stands on the ability of microglia to exert finely tuned phagocytic activity and to synthesize a large range of cytokines, which not only control neuronal cell fate, but also the formation, selection, maintenance and remodeling of interneuronal synapses. Thus, during brain development, microglia successively engage distinct activation programs that are in close synchrony with the stepwise establishment and maturation of neuronal circuits ${ }^{65}$. Moreover, in the mature brain, microglia constantly operate a complementdependent phagocytosis of poorly-active synapses, thus preventing inappropriate connectivity. Lastly, several lines of evidence indicate that specific inflammatory cytokines regulate synaptic activity and function under physiological conditions ${ }^{66}$. TNF-alpha secreted by glial cells preserves the efficacy of excitatory synapses ${ }^{67}$, and IFN- $\gamma$ is a key molecular support for excitatory synapses ${ }^{68}$ and neuronal circuitry involved in social behavior ${ }^{69}$. With regard to the myelin compartment, it is also worth noting that myelination of axons is a highly dynamic process that is coupled to synaptic activity $^{70-74}$, and thus indirectly linked to physiological inflammation. In addition, microglia exert direct effects on the development and myelinating functions of oligodendrocytes (the myelin-forming cells) via the synthesis of $\mathrm{H}$-ferritin ${ }^{75}$ and M2-type cytokines ${ }^{76}$. Overall, the formation, maintenance and plasticity of two major brain molecular compartments, namely myelin and interneuronal synapses, involve a set of exquisitely-controlled immune mechanisms. In this regard, physiological inflammation appears to be required to ensure proper CNS functions ${ }^{66}$. In addition, while inflammatory mechanisms are now recognized in shaping brain development in rodents and humans, a major distinctive feature of the human brain is the duration of its development over a period of time that extends from early embryonic stages until adolescence ${ }^{77}$ and beyond ${ }^{78}$. Indeed, the acquisition of a fully-operative neuronal circuitry supporting primary human-specific brain skills (regarding emotional, cognitive and sensory-motor functions) is a decade-long process that is intimately associated to myelination ${ }^{78}$. Along this line, the proliferation of neuronal progenitors and their differentiation into cortical neurons, usually designated by the term "corticogenesis", was shown to be much slower and complex in humans compared to rodents ${ }^{79}$. Thus, besides development and maturation, adult synaptic plasticity, allowing the constant remodeling of synaptic connections in order to maintain, extend and/or reorganize neuronal circuits, is likely responsible for a massive exposure of the immune system to synapse- and myelin-related antigens throughout life. The recent demonstration of a rich lymphatic vasculature, which drains brain antigens to cervical lymph nodes ${ }^{80,81}$, further supports this view.
Non-CNS autoimmune disorders target CNS antigens While CNS autoimmune diseases are generally relatively infrequent, many autoantigens identified in non-CNS autoimmune pathologies are enriched in the synaptic fraction of the developing and/or mature brain. Below is a non-exhaustive list of such autoantigens:

1) GAD65: Glutamate decarboxylase 65 (GAD2), considered the main autoantigen in diabetes type $I^{82}$, is a synaptic enzyme that catalyzes $\gamma$-aminobutyric acid (GABA) synthesis from glutamate. Its synaptic expression in inhibitory terminals (i.e. axon terminals from neurons transmitting inhibitory inputs) is indispensable to the effective functioning of the GABAergic system (all neurons for which the primary neurotransmitter is GABA) ${ }^{83}$.

2) AchR: Myasthenia gravis is mediated by autoantibodies targeting the AchR (acetylcholine receptor) on the post-synaptic membrane of the neuromuscular junction ${ }^{84}$. However, acetycholine is also a key neurotransmitter in the CNS, and AchR-mediated synaptic transmission is essential in crucial cognitive functions, such as memory ${ }^{85}$.

3) HSPA5 and other heat shock proteins: The human stress protein, HSPA5 (also known as BIP or GRP78), belonging to the heat shock protein family A (HSP70), is one of the autoantigens involved in the pathophysiology of rheumatoid arthritis ${ }^{86,87}$. It is also a major component of the synaptic glutamate receptor complex ${ }^{88}$. Similarly, the heat shock protein HSP60, a predominant target of physiological autoimmunity ${ }^{89}$, is abundantly expressed in axon terminals ${ }^{90}$, and mutations in the HSP60 gene result in a human disorder affecting motor neurons (autosomal recessive spastic paraplegia 13) ${ }^{91}$.

4) Small nuclear ribonucleoproteins: Small nuclear ribonucleoproteins (snRNPs) are core components of the spliceosome machinery and the main autoantigens toward which anti-ribonucleotide antibodies are directed in systemic lupus erythematous (SLE) and Sjögren's syndrome ${ }^{92}$. In neurons, specific families of mRNAs are exported toward axon terminals and synapses in structures called RNA granules or ribonucleoprotein particles. Such structures are essential to the proper trafficking of specific mRNA species at distance from the soma and their local translation in the synaptic compartment $^{93}$. Mutations or deletions in genes coding for RNAbinding proteins (RBPs) are involved in numerous inherited CNS disorders ${ }^{94}$, including fragile-X mental retardation ${ }^{95}$, spinal muscular atrophy and spinocerebellar ataxia ${ }^{96}$, as well as familial forms of the following neurological conditions: autism ${ }^{97,98}$; amyotrophic lateral sclerosis ${ }^{99}$; and fronto-temporal lobar degeneration ${ }^{100}$. The whole spectrum of RNAs and proteins that are complexed to such neuronally-expressed RBPs is currently extensively explored by systemic approaches ${ }^{94,101}$ and include several snRNPs targeted by autoantibodies in SLE or Sjögren's syndrome. These snRNPS comprise of the La autoantigen Ssb, which binds FRMP (fragile X mental retardation protein) ${ }^{101}$, the U1 snRNP, which interacts with SMN (survival of motor neurons) ${ }^{102}$, and the small non-coding RNA called Y RNA, a component of Ro60 ribonucleoprotein particle, which binds neuronal ELAV-like protein ${ }^{103}$. Finally, ribosomal 
proteins are themselves targeted by both pathological autoimmunity in SLE patients ${ }^{104}$ and physiological autoimmunity in healthy individuals ${ }^{105}$. Again, synapses are specifically enriched in ribosomes and allow crucial synaptic proteins to be synthesized in a timely manner ${ }^{106,107}$.

5) Basement membrane proteins: Autoimmunity against collagen IV and laminins, two major components of basement membranes, is responsible for the development of anti-glomerular basement membrane glomerulonephritis, Goodpasture's disease ${ }^{108}$ and several autoimmune skin disorders ${ }^{109}$. Recent evidence indicates that synapses are embedded in a extracellular matrix microenvironment, in which collagen IV and laminins are not only abundant, but critically involved in synapse morphogenesis and synaptic remodeling ${ }^{110-113}$.

6) Tyrosine hydroxylase: Vitiligo is a frequent autoimmune disease characterized by an immune-mediated destruction of melanocytes leading to skin depigmentation ${ }^{114}$. Interestingly, the biochemical pathways allowing the synthesis of melanin and dopamine respectively present major similarities ${ }^{115,116}$, and the intra-CNS grafting of melanocytes was recently proposed as a therapeutic approach for Parkinson's disease, a neurodegenerative disorder affecting dopaminergic neurons ${ }^{115}$. In this regard, tyrosine hydroxylase, a major enzyme of the dopamine synthesis pathway in neurons is also essential to melanin synthesis and is targeted by autoantibodies in vitiligo ${ }^{117,118}$. Also, the melanin-concentrating hormone receptor 1 (MCHR1), another identified autoantigen in vitiligo $^{119}$, is expressed by a subpopulation of CNS neurons and its ligand, $\mathrm{MCH}$, is indeed a neuropeptide regulating energy balance, sleep and mood ${ }^{120,121}$.

7) Thyroglobulin and acetylcholinesterase: Thyroglobulin (TG) and thyroid peroxidase (TPO) are the two main thyroid autoantigens targeted in Hashimoto's disease ${ }^{122}$. While anti-TPO antibodies have been shown to bind a subpopulation of astrocytes ${ }^{123}$, it is worth noting that anti-TG autoantibodies recognize an acetylcholinesterase domain that is essential to both the immunogenicity of $\mathrm{TG}^{124-126}$ and its function ${ }^{127,128}$. Thus, cross-reactivity between TG and acetylcholinesterase, a target autoantigen in Myasthenia gravis, was proposed as a mechanism of ocular muscle dysfunction in Hashimoto's disease ${ }^{124}$. As mentioned earlier, the cholinergic system, essentially supported by functional interactions between acetylcholine, acetylcholinesterase and AchR, is crucial to the execution of major cognitive tasks, such as learning and memory.

\section{Cognitive alterations are frequently observed in patients} suffering from non-CNS autoimmune diseases

Subclinical cognitive alterations, as well as psychiatric symptoms, are observed in a large array of non-CNS autoimmune diseases. Interestingly, specific antibody signatures have been shown to be associated with such neurological or psychiatric manifestations, which argues against a non-specific inflammatory process that would essentially involve innate immune mechanisms. Below is a list of the main non-CNS autoimmune disorders that may associate with cognitive and/or psychiatric symptoms:
1) SLE and Sjögren's syndrome: Besides purely neuropsychiatric forms of SLE, subtle to major cognitive alterations were demonstrated in up to $20 \%$ of SLE patients ${ }^{129}$. Cognitive clinical signs in SLE are accompanied with high titers of anti-N-methyl-D-aspartate receptor (NMDA; also named NR2 glutamate receptor) and/or anti-ribosomal antibodies ${ }^{130,131}$. Similarly, cognitive dysfunctions along with brain structural alterations, detectable by magnetic resonance imaging (MRI), were reported in up to $65 \%$ patients suffering from primary Sjögren's syndrome ${ }^{132-134}$. As in SLE patients, a correlation was observed between titers of anti-NR2 antibodies (in the serum or cerebrospinal fluid) and clinical sores of cognitive dysfunction ${ }^{130,135}$.

2) Hashimto's thyroiditis: Hashimoto's encephalopathy, also known as steroid-responsive encephalopathy associated with autoimmune thyroiditis (SREAT), is a rare condition in which anti-TPO antibodies are involved ${ }^{136}$. However, apart from SREAT, autoimmune thyroiditis (AIT) patients who are in an euthyroid state, suffer from mild to severe cognitive alterations correlating with serum levels of anti-thyroid antibodies, in particular anti-TPO and anti- TG antibodies ${ }^{137,138}$.

3) Rheumatoid arthritis: While the rate of motor or sensory neurological symptoms is relatively low in rheumatoid arthritis (RA) patients, the incidence of mood disorders is estimated to reach up to $70 \%{ }^{139}$. Moreover, in independent studies, mild cognitive deficits were demonstrated in more than $70 \%$ of RA patients and were associated with MRI or biological signs of altered CNS tissue integrity ${ }^{140,141}$.

4) Psoriasis: Psoriasis is a chronic skin disorder that may also target joints, and for which several candidate autoantigens have been identified $^{142}$, including, surprisingly, the melanocytic autoantigen ADMTSL5 $^{143}$. The impact of psoriasis plaques on self-esteem and mood is well-described and the role of psychological stress as a trigger of psoriasis recurrence is also robustly documented ${ }^{144}$. However, measurable signs of subtle cognitive impairment are also observed in psoriasis patients ${ }^{145,146}$, even during the early phases of the disease ${ }^{145}$.

5) Crohn's disease: Inflammatory bowel diseases, including Crohn's disease (CD), associate with distinct profiles of circulating autoantibodies directed notably against glycans, GP2 and GM-CSF ${ }^{147}$. While glycans were shown to be specifically enriched in synapses ${ }^{148,149}$, the intra-CNS expression of GP2 and GM-CSF in the developing or mature brain is still lacking. However, two recent MRI studies performed in CD patients demonstrated marked structural brain alterations ${ }^{150,151}$ that correlated with cognitive dysfunction ${ }^{150}$.

Myelin and synapses are by far the most frequently targeted compartments in CNS autoimmune disorders

Besides multiple sclerosis, during which one or several myelin autoantigens are targeted ${ }^{152}$, a flurry of rare CNS autoimmune disorders, notably including paraneoplastic syndromes (PNS), have been characterized in the past decade. Interestingly, not only do a great majority of PNS have a purely neurological expression, but 
autoantigens in PNS were found to derive essentially from the synaptic compartment ${ }^{153}$. Moreover, other CNS autoimmune disorders not associated with neoplasms also target synaptic proteins, and the term "autoimmune synaptopathies" has been proposed to designate such pathologies ${ }^{153}$. The following is a non-exhaustive list of the synaptic autoantigens currently identified: GAD65 (glutamic acid decarboxylase) $)^{154}$; NMDAR (N-methyl-D-aspartate receptor) ${ }^{155}$; AMPAR $\quad(\alpha$-amino-3-hydrozy-5-methyl-4-isoxazolepropionic acid receptor) ${ }^{156}$; Caspr2 (contactin-associated protein-like 2) ${ }^{157}$; LGI-1 (leucine-rich glioma-inactivated protein 1) ${ }^{158}$; GABA-B receptor $(\gamma \text {-aminobutyric acid receptor } \mathrm{B})^{159}$; GABA-A receptor $(\gamma \text {-aminobutyric acid receptor A })^{160}$; mGluR5 (metabotropic glutamate receptor 5) ${ }^{161}$; GlyR (glycine receptor) ${ }^{162}$; NRXN3 (neurexin$3 \alpha)^{163}$; AMPH (amphiphysin) ${ }^{164}$.

\section{On the "co-evolution" of the immune and nervous systems}

As shown above, a high number of antigens targeted in CNS or non-CNS autoimmune diseases belong either to the myelin or synaptic compartments. Even though such target autoantigens are evidently also expressed in non-CNS locations, the important questions arising from such an observation are why and how the human immune repertoires are skewed toward brain superautoantigens. As discussed earlier, both anti-tumoral immunity and maintenance of tissue integrity are essential functions that can be assigned to physiological autoimmunity ${ }^{59,165}$. Nevertheless, these functions do not appear to afford an evolutionary advantage to humans over other species endowed with an adaptive immune system. One may consider that the human species is indeed essentially characterized by a particular ability to operate complex cognitive tasks and perform exquisitely precise motor programs. On this basis, it can be hypothesized that CNS-derived autoantigens are major targets of physiological immunity in humans. Moreover, at the scale of evolution, physiological autoimmunity against CNS auto-antigens may reflect not only the development of fine cognitive and motor functions in a given species, but the extent to which support to these functions is afforded by adaptive immunity in this species.

\section{From symbiosis to phylosymbiosis}

Interactions between humans and their gut microbiota is an illustrative example of what could be termed an immune-mediated symbiotic relationship. On one hand, gut microbiota constantly stimulate the adaptive immune system and shape T-cell and antibody repertoires, thus expanding, through cross-reactivity, the diversity of adaptive immune responses. In turn, the adaptive immune system tightly controls the composition of gut microbiota and favors the development and maintenance of a longlasting commensal flora, which is benefitial to the host. Immune response against gut microbiota fluctuates over time and serum antibody titers against microbiota-derived antigens are submitted to variations, determined by epitope-specific clonal expansion and dominance $^{166}$. Thus, more generally, the commensal flora residing in the skin, gut, lungs and urogenital tract permanently stimulates, shapes and modulates our whole immune repertoire ${ }^{167-169}$. In this state of "immunity by equilibrium" ${ }^{169}$, populations of Tregs, deriving either from the thymus or peripherally-generated, play a crucial role in the neonatal development of tissue-specific tolerance toward symbiotic flora components ${ }^{170-174}$. While symbiosis corre- sponds to a process of co-development and mutual support between species, co-evolution is defined by mutual selective pressure exerted by two species to the benefits of both species. Interestingly, the term phylosymbiosis was recently proposed to depict the parallel demonstrated between the phylogeny of host-associated microbial communities and the phylogeny of species hosting these distinct communities ${ }^{175}$. Of note, phylosymbiosis appears to be essentially mediated by the immune system of the host ${ }^{175}$. In this regard, host/microbiota symbiotic interactions could be considered as resulting from a process of immune-mediated co-evolution of organisms.

\section{From co-development to co-evolution}

By analogy with the notions of phylosymbiosis and co-evolution, it is proposed below that the immune and nervous systems not only co-develop at the scale of an individual, but have co-developed during evolution. This idea essentially stems from the crucial demonstration that human newborns harbor an $\operatorname{IgM}$ antibody repertoire directed against autoantigens $\mathrm{s}^{34,35,38}$. Obviously, and as previously mentioned, since the amnion forms a sterile environment, crossreactivity against microbiota-derived antigens cannot explain such an observation. Interestingly, while the full array of autoantigens targeted by IgM in newborns remains to be identified, many of the currently known targeted autoantigens are components of the myelin or synaptic compartments. These include: GAD65, MOG and acetylcholinesterase (cf supra); HSP60, a mitochondrial chaperonin whose genetically-determined alterations lead to a familial form of motor neuron disease ${ }^{176}$ ( $\mathrm{cf}$ supra); myosin, a protein whose brain isoform is abundantly expressed in synapses ${ }^{177,178}$; galectin-1 and -3 , two neuronally expressed molecules that bind to the synaptic RNA-binding protein SMN (Survival Motor Neuron) ${ }^{179,180}$; B2-microglobulin, a key immune molecule also required for proper CNS development and plasticity ${ }^{181}$.

These observations suggest that the developing CNS provides a highly diverse array of autoantigens that may stimulate and somehow educate effector $\mathrm{T}$ and $\mathrm{B}$ cells during the prenatal period. The main advantage conferred to the host by such an educational process would be a pre-natal expansion of memory lymphocytes, which, through cross-reactivity, would provide a larger immune coverage against infectious agents (including pathological microbiota).

Beyond development, it is also suggested that throughout the lifetime of an individual, brain-derived autoantigens may constantly shape the repertoire of memory lymphocytes and provide tonic signals for the survival and self-renewal of naïve lymphocytes ${ }^{182-184}$. As shown above, synaptic remodeling and myelin renewal are two major hallmarks of physiological neural functions during the life span of an individual. In particular, the learning-mediated establishment of new neuronal circuits, their selection and maintenance or elimination implies a constant adjustment of our neural repertoires (neural repertoires being defined here as all neuronal populations and synaptic circuits available for cognitive or sensorimotor tasks at a given time). Not only will the brain continue to develop and maturate until early adulthood, but cognitive and sensori-motor functions in the mature CNS are inherently-linked to the plasticity of synapses and myelin sheaths. Overall, one may propose that, simi- 
larly to microbiota, the CNS constantly fuels the immune system with antigens that shape and modulate our T- and B-cell repertoires. Conversely, the CNS-instructed diversification of our immune repertoires may ensure that essential synaptic circuits are reinforced by cognition-promoting autoreactive lymphocytes. Thus, at the scale of an individual, the acquisition and maintenance of the immune and neural repertoires may be somehow coupled via a process of mutual development and support.

What about evolution? It is proposed here that such a coupling of immune and neural repertoires may have been a driving force of evolution. In this theoretical model, the nervous and immune systems would have been submitted to a co-evolution-like process, consisting of a mutual selective pressure exerted by both systems to the benefits of the host. On one hand, through cognitionpromoting immunity, the evolutionary-determined emergence and diversification of adaptive immunity would have provided support to new neural repertoires. At the same time, the evolutionary-determined diversification of neural repertoires would have promoted new immune repertoires (and a subsequent larger ability to tackle infections) via exposure to a larger array of CNS-derived antigens. Accordingly, it may be predicted that among species endowed with an adaptive immune system: i) Diversity of the germline-encoded and realized (mature) immune repertoires parallels the diversity exhibited by the neural repertoire; ii) cognition-promoting autoimmunity is quantitatively and qualitatively scaled to the level of complexity that each species exhibits with regard to cognitive functions; and iii) genes involved in the diversification of both immune and neural repertoires have had a major evolutionary impact. Importantly, this model would explain why the realized human TCR repertoire overcomes the one of rodents by a factor of $10^{185}$.

\section{Critical points and limitations of the co-development/co- evolution model}

Co-development and co-evolution processes may also link the immune system to non-CNS organs: The theoretical model discussed above may be considered as neurocentric. Indeed, the concept of protective autoimmunity likely applies also to nonCNS organs, and the CNS is not the only source of superautoantigens. Thus, in addition to synaptic and myelin antigens, other families of autoantigens are: i) highly renewed, ii) abundantly exposed to the immune system, iii) involved in crucial organspecific functions, and iv) expressed in a context of physiological inflammation. Evolutionary-determined adaptive immune responses against such non-CNS superautoantigens may provide a large range of functional benefits that do not relate to the CNS. As shown below, some of these may be species-specific (for instance, provide trophic support to organs that are essential to the survival and adaptation of a given species), while others may be shared between species (for instance, fighting against cancer cells).

Species-restricted vs inter-species superautoantigens: The advantages conferred to the host by an adaptive immune response directed against a superautoantigen may persist across evolution. In particular, one could anticipate that a substantial share of public TCRs are directed against two categories of superautoantigens: species-restricted and inter-species superautoantigens.
1) Species-restricted superautoagntigens: The choice of the term "species-restricted" refers to the notion that such antigens are not necessarily expressed in a species-specific manner. By contrast, the adaptive response mounted against these antigens is speciesspecific and confers a species-specific evolutionary advantage to the host. Notably, this may be the case for a group of brainderived antigens that could have emerged as superautoantigens in Homo sapiens.

2) Inter-species superautoantigens: These antigens are not only expressed across distinct (or all) species endowed with an adaptive immune response, but the T-cell response mounted against these antigens confer an evolutionary advantage that is shared between such species.

Natural antibodies directed against CNS antigens may exert only an indirect effect on neural repertoires: Previous studies showed that CNS-directed antibodies can be detected in the blood in a large range of the healthy population ${ }^{186,187}$. However, antibodies do not or only poorly cross the blood-brain barrier, and cognitionpromoting autoimmunity was demonstrated to rely on T-cells rather than autoantibodies ${ }^{54-56,188}$. Thus, while T-cells and neural repertoires may be mutually supportive, only a one-way functional connection may link the antibody and neural repertoires. On the one hand, exposure of brain antigens to the immune system would benefit the host via an expansion/diversification of both the antibody and TCR repertoires, while on the other hand, only "self"reactive T-cells (but not autoantibodies) would provide support to neural repertoires. Another explanation, not exclusive from the former one, would be that natural autoantibodies directed against CNS antigens participate in the afferent phase of T-cell mediated cognition-promoting immune responses. Engulfment of CNSderived antigens opsonized or captured by secreted antibodies or, for B-cells, by membrane-bound immunoglobulins, may indeed result in antigen presentation to T-cells, notably in cervical lymph nodes.

Natural autoantibodies and "self"-reactive T-cells may provide two separate arms of protective autoimmunity: Although this point remains to be experimentally explored, one may anticipate that autoantibodies and "self"-reactive T-cells are targeting distinct (yet partially overlapping) groups of superautoantigens. T-cells and antibody repertoires would thus provide distinct and complementary facets of protective autoimmunity. One may suggest that for some (or possibly many) natural autoantibodies, an essential function is to somehow scavenge and buffer proteins that are renewed or exposed at a high rate in the blood. Supporting this view, spleen marginal zone B-cells, whose hosting tissue is directly plugged on the blood stream, are considered as a major source of natural autoantibodies ${ }^{189,190}$.

\section{Clinical implications}

Autoimmunity viewed as a neurodevelopmental disorder

The assumption that immune and neural repertoires are mutually supportive during developmental and post-developmental periods has potentially important clinical implications. In particular, if brain development, from the prenatal period to early adulthood, has a major impact on the acquisition and maintenance of immune repertoires, an endogenous neural origin of pathological autoimmunity 
may be envisioned. The window of time and immune context during which brain superautoantigens are initially exposed could be a major determinant of the diversity of the T-cell repertoire. In other words, a proper exposure to brain superautoantigens would determine the generation, maintenance and expansion of T-cells that not only recognize brain superautoantigens, but harbor a phenotype and functional profile that are ideally suited to support neural repertoires (i.e. ad hoc homing properties and ad hoc profiles of cytokines and neurotrophic factors). Similar principles may apply to B cells and natural autoantibodies, with the limitations discussed previously.

Several elements of the literature support the notion that neural and immune repertoires mutually develop in humans. Cognitive and behavioral alterations are observed in children suffering from several categories of genetically-determined immunodeficiencies. These include severe combined immunodeficiencies $^{191}$ and the Di Georges syndrome, which associates thymic hypoplasia, cognitive deficits ${ }^{192}$ and psychiatric manifestations, such as autism and schizophrenia ${ }^{193}$. Conversely, complex immune alterations have been reported in patients suffering from the two most frequent neuropsychiatric and neurodevelopmental human disorders: autism and schizophrenia. Schizophrenia is associated with a higher incidence of autoimmune disorders, including Grave's disease, psoriasis and celiac disease ${ }^{194}$. Moreover, a number of studies have demonstrated a large range of immune alterations in the blood of schizophrenic patients ${ }^{195,196}$. Also, the high incidence of autoimmune disorders in autistic patients and their siblings has suggested that autoimmune mechanisms may be involved in the pathophysiology of autism ${ }^{197}$. However, in accordance with the co-development/co-evolution model, another explanation could be that the neurodevelopmental alterations characterizing autism and schizophrenia are the cause rather than the consequence of profound alterations of the immune repertoires, which may lead to pathological autoimmunity in a subgroup of these patients.

Interestingly, genome-wide association studies also provide important support to the co-development/co-evolution model. Indeed, as discussed earlier, this model predicts that genes involved in the diversification of both immune and neural repertoires have had a major evolutionary impact. Accordingly, there is now compelling evidence that genetic susceptibility to autism and schizophrenia is conferred, for some parts, by immune-related genes, including HLA genes ${ }^{198-201}$.

\section{Immune repertoires under the grip of the CNS}

Besides periods of co-development and co-maturation, it is proposed that neural and immune repertoires mutually fuel each other during the whole life of an individual. Considering that CNS-derived antigens, similarly to microbiota-derived antigens, constantly shape immune repertoires, implies that mental state, learning tasks, cognitive activities and/or the execution of sensori-motor programs could exert major and specific effects on immune repertoires. Stress-induced alterations of the immune response is now extensively documented and is known to rely on two main pathways: the hypothalamus-pituitary-adrenal axis and the autonomic nervous system (ASN) pathway ${ }^{202,203}$. Recently, the brain reward system was also shown to deeply impact immune responses via signaling through the $\mathrm{ASN}^{204}$. CNS-derived superautoantigens and their instructing roles on immune repertoires could thus provide another mechanism of brain-induced immunomodulation. More generally, demonstrating that neural and immune repertoires are functionally coupled could pave the way to innovative therapeutic strategies based on the control of adaptive immune responses by cognitive and/or sensorimotor tasks.

\section{Experimental insights}

The assessment of immune repertoires by system biology approaches $^{34,36,43,205}$ should allow the determination of whether or not cognitive activities, sensori-motor tasks and mental state directly impact immune repertoires. In particular, immune repertoires should be explored in experimental settings known to induce an increased synaptic plasticity in rodents (notably via enrichment of the environment). Similarly, murine genetic models of schizophrenia or autism should be investigated with regard to alterations of immune repertoires (this should be performed only if immune alterations are not expected to occur as a direct consequence of a given genetic manipulation). The same strategy could be also applied to murine models of mood disorders. Of note, recently-developed technologies, such as optogenetics and chemicogenetics, are currently being harnessed to unravel new links between the brain and immune system ${ }^{206}$. Such innovative approaches should allow to precisely determine the impact exerted by the activation of specific synaptic circuits on: i) the peripheral T- and B-cell repertoires; and ii) the exposure of specific CNS antigens, notably via their draining to cervical lymph nodes. Finally, a global analysis of immune repertoires should be performed in human patients suffering from autism, schizophrenia or mood disorders. Notably, one may anticipate that qualitative or quantitative alterations of public TCRs may occur under these clinical conditions.

\section{Competing interests}

No competing interests were disclosed.

\section{Grant information}

The author(s) declared that no grants were involved in supporting this work.

\section{Acknowledgments}

Thanks to Laurent Pays and Nathalie Davoust for their scientific and personal supports. 
1. Perricone C, Colafrancesco S, Mazor RD, et al.: Autoimmune/inflammatory syndrome induced by adjuvants (ASIA) 2013: Unveiling the pathogenic, clinical and diagnostic aspects. $J$ Autoimmun. 2013; 47: 1-16. PubMed Abstract | Publisher Full Text

2. Cohen IR: The cognitive paradigm and the immunological homunculus. Immunol Today. 1992; 13(12): 490-4.

PubMed Abstract | Publisher Full Text

3. Cohen IR: The cognitive principle challenges clonal selection. Immunol Today. 1992; 13(11): 441-4.

PubMed Abstract | Publisher Full Text

4. Haggard $P$, Taylor-Clarke M, Kennett S: Tactile perception, cortical representation and the bodily self. Curr Biol. 2003; 13(5): R170-R173.

PubMed Abstract | Publisher Full Text

5. Yang TT, Gallen CC, Schwartz BJ, et al:: Noninvasive somatosensory homunculus mapping in humans by using a large-array biomagnetometer. Proc Natl Acad Sci U S A. 1993; 90(7): 3098-3102.

PubMed Abstract | Publisher Full Text | Free Full Text

6. Huber D, Gutnisky DA, Peron S, et al.: Multiple dynamic representations in the motor cortex during sensorimotor learning. Nature. 2012; 484(7395): 473-478. PubMed Abstract | Publisher Full Text | Free Full Text

7. Barrière G, Simmers J, Combes D: Multiple mechanisms for integrating proprioceptive inputs that converge on the same motor pattern-generating network. J Neurosci. 2008; 28(35): 8810-8820.

PubMed Abstract | Publisher Full Text

8. Qi HX, Jain N, Collins CE, et al:: Functional organization of motor cortex of adult macaque monkeys is altered by sensory loss in infancy. Proc Natl Acad Sci U S A. 2010; 107(7): 3192-3197.

PubMed Abstract | Publisher Full Text | Free Full Text

9. Khazipov R, Sirota A, Leinekugel $X$, et al.: Early motor activity drives spindle bursts in the developing somatosensory cortex. Nature. 2004; 432(7018): 758-761. PubMed Abstract | Publisher Full Text

10. Arce-McShane FI, Ross CF, Takahashi K, et al.: Primary motor and sensory cortical areas communicate via spatiotemporally coordinated networks at multiple frequencies. Proc Natl Acad Sci U S A. 2016; 113(18): 5083-5088. PubMed Abstract | Publisher Full Text | Free Full Text

11. Ostry DJ, Darainy M, Mattar AA, et al.: Somatosensory plasticity and motor learning. J Neurosci. 2010; 30(15): 5384-93.

PubMed Abstract | Publisher Full Text | Free Full Text

12. Wong JD, Wilson ET, Gribble PL: Spatially selective enhancement of proprioceptive acuity following motor learning. J Neurophysiol. 2011; 105(5): 2512-21. PubMed Abstract | Publisher Full Text | Free Full Text

13. Nelson SB, Valakh V: Excitatory/Inhibitory Balance and Circuit Homeostasis in Autism Spectrum Disorders. Neuron. 2015; 87(4): 684-698. PubMed Abstract | Publisher Full Text | Free Full Text

14. Sporns O, Betzel RF: Modular Brain Networks. Annu Rev Psychol. 2016; 67: 613-40. PubMed Abstract | Publisher Full Text | Free Full Text

15. Des Rosiers MH, Sakurada O, Jehle J, et al:: Functional plasticity in the immature striate cortex of the monkey shown by the [14C]deoxyglucose method. Science. 1978; 200(4340): 447-9.

PubMed Abstract | Publisher Full Text

16. Tognini P, Napoli D, Tola J, et al:: Experience-dependent DNA methylation regulates plasticity in the developing visual cortex. Nat Neurosci. 2015; 18(7): 956-8. PubMed Abstract | Publisher Full Text

17. Frégnac $\mathrm{Y}$, Imbert M: Development of neuronal selectivity in primary visual cortex of cat. Physiol Rev. 1984; 64(1): 325-434. PubMed Abstract

18. Wang X, Peelen MV, Han Z, et al.: How Visual Is the Visual Cortex? Comparing Connectional and Functional Fingerprints between Congenitally Blind and Sighted Individuals. J Neurosci. 2015; 35(36): 12545-59. PubMed Abstract | Publisher Full Text

19. Miquelajauregui A, Kribakaran S, Mostany R, et al.: Layer 4 pyramidal neurons exhibit robust dendritic spine plasticity in vivo after input deprivation. J Neurosci. 2015; 35(18): 7287-94.

PubMed Abstract | Publisher Full Text | Free Full Text

20. Butko MT, Savas JN, Friedman B, et al.: In vivo quantitative proteomics of somatosensory cortical synapses shows which protein levels are modulated by sensory deprivation. Proc Natl Acad Sci U S A. 2013; 110(8): E726-35. PubMed Abstract | Publisher Full Text | Free Full Text

21. Simons DJ, Land PW: Early experience of tactile stimulation influences organization of somatic sensory cortex. Nature. 1987; 326(6114): 694-7. PubMed Abstract | Publisher Full Text

22. Hooks BM, Chen C: Critical periods in the visual system: changing views for a model of experience-dependent plasticity. Neuron. 2007; 56(2): 312-26. PubMed Abstract | Publisher Full Text

23. Espinosa JS, Stryker MP: Development and plasticity of the primary visual cortex. Neuron. 2012; 75(2): 230-49.

PubMed Abstract | Publisher Full Text | Free Full Text

24. Holtmaat A, Svoboda K: Experience-dependent structural synaptic plasticity in the mammalian brain. Nat Rev Neurosci. 2009; 10(9): 647-58. PubMed Abstract | Publisher Full Text

25. Wandell BA, Smirnakis SM: Plasticity and stability of visual field maps in adult primary visual cortex. Nat Rev Neurosci. 2009; 10(12): 873-84. PubMed Abstract | Publisher Full Text | Free Full Text

26. Calford MB, Tweedale R: Immediate and chronic changes in responses of somatosensory cortex in adult flying-fox after digit amputation. Nature. 1988; 332(6163): 446-8

PubMed Abstract | Publisher Full Text

27. Makin TR, Scholz J, Filippini N, et al:: Phantom pain is associated with preserved structure and function in the former hand area. Nat Commun. 2013; 4: 1570. PubMed Abstract | Publisher Full Text | Free Full Text

28. Tiriac A, Blumberg MS: Gating of reafference in the external cuneate nucleus during self-generated movements in wake but not sleep. eLife. 2016; 5: pii: e18749.

PubMed Abstract | Publisher Full Text | Free Full Text

29. Blumberg MS, Marques HG, lida F: Twitching in sensorimotor development from sleeping rats to robots. Curr Biol. 2013; 23(12): R532-R537. PubMed Abstract | Publisher Full Text | Free Full Text

30. Tiriac A, Del Rio-Bermudez C, Blumberg MS: Self-generated movements with "unexpected" sensory consequences. Curr Biol. 2014; 24(18): 2136-2141. PubMed Abstract | Publisher Full Text | Free Full Text

31. Desmurget M, Richard N, Harquel S, et al:: Neural representations of ethologically relevant hand/mouth synergies in the human precentral gyrus. Proc Natl Acad Sci U S A. 2014; 111(15): 5718-5722. PubMed Abstract | Publisher Full Text | Free Full Text

32. Cohen IR, Young DB: Autoimmunity, microbial immunity and the immunological homunculus. Immunol Today. 1991; 12(4): 105-110. PubMed Abstract | Publisher Full Text

33. Madi A, Bransburg-Zabary S, Maayan-Metzger A, et al:: Tumor-associated and disease-associated autoantibody repertoires in healthy colostrum and maternal and newborn cord sera. J Immunol. 2015; 194(11): 5272-5281. PubMed Abstract | Publisher Full Text | Free Full Text

34. Merbl Y, Zucker-Toledano M, Quintana FJ, et al:: Newborn humans manifest autoantibodies to defined self molecules detected by antigen microarray informatics. J Clin Invest. 2007; 117(3): 712-718. PubMed Abstract | Publisher Full Text | Free Full Text

35. Madi A, Hecht I, Bransburg-Zabary S, et al.: Organization of the autoantibody repertoire in healthy newborns and adults revealed by system level informatics of antigen microarray data. Proc Natl Acad Sci U S A. 2009; 106(34): 14484-14489.

PubMed Abstract | Publisher Full Text | Free Full Text

36. Madi A, Kenett DY, Bransburg-Zabary S, et al.: Network theory analysis of antibody-antigen reactivity data: the immune trees at birth and adulthood. PLoS One. 2011; 6(3): e17445

PubMed Abstract | Publisher Full Text | Free Full Text

37. Madi A, Kenett DY, Bransburg-Zabary S, et al:: Analyses of antigen dependency networks unveil immune system reorganization between birth and adulthood. Chaos. 2011; 21(1): 016109.

PubMed Abstract | Publisher Full Text

38. Madi A, Bransburg-Zabary S, Kenett DY, et al.: The natural autoantibody repertoire in newborns and adults: a current overview. Adv Exp Med Biol. 2012; 750: 198-212.

PubMed Abstract | Publisher Full Text

39. Bluestone JA, Bour-Jordan $\mathrm{H}$, Cheng $\mathrm{M}$, et al:: T cells in the control of organspecific autoimmunity. J Clin Invest. 2015; 125(6): 2250-2260. PubMed Abstract | Publisher Full Text | Free Full Text

40. Simpson LJ, Ansel KM: MicroRNA regulation of lymphocyte tolerance and autoimmunity. J Clin Invest. 2015; 125(6): 2242-2249. PubMed Abstract | Publisher Full Text | Free Full Text

41. Marson A, Housley WJ, Hafler DA: Genetic basis of autoimmunity. J Clin Invest 2015; 125(6): 2234-2241.

PubMed Abstract | Publisher Full Text | Free Full Text

42. Covacu R, Philip H, Jaronen M, et al.: System-wide Analysis of the T Cel Response. Cell Rep. 2016; 14(11): 2733-2744. PubMed Abstract | Publisher Full Text | Free Full Text

43. Madi A, Shifrut E, Reich-Zeliger S, et al:: T-cell receptor repertoires share a restricted set of public and abundant CDR3 sequences that are associated with self-related immunity. Genome Res. 2014; 24(10): 1603-1612. PubMed Abstract | Publisher Full Text | Free Full Text

44. Cohen IR: Activation of benign autoimmunity as both tumor and autoimmune disease immunotherapy: a comprehensive review. J Autoimmun. 2014; 54 $112-117$.

PubMed Abstract | Publisher Full Text

45. Ron-Harel N, Cardon M, Schwartz M: Brain homeostasis is maintained by "danger" signals stimulating a supportive immune response within the brain's borders. Brain Behav Immun. 2011; 25(5): 1036-1043.

PubMed Abstract | Publisher Full Text 
46. Schwartz M, Shechter R: Protective autoimmunity functions by intracranial immunosurveillance to support the mind: The missing link between health and disease. Mol Psychiatry. 2010; 15(4): 342-354. PubMed Abstract | Publisher Full Text

47. Schwartz M, Ziv Y: Immunity to self and self-maintenance: a unified theory of brain pathologies. Trends Immunol. 2008; 29(5): 211-219. PubMed Abstract | Publisher Full Text

48. Kipnis J: Multifaceted interactions between adaptive immunity and the central nervous system. Science. 2016; 353(6301): 766-771. PubMed Abstract | Publisher Full Text

49. Meyer S, Woodward M, Hertel C, et al.: AIRE-Deficient Patients Harbor Unique High-Affinity Disease-Ameliorating Autoantibodies. Cell. 2016; 166(3): 582-595. PubMed Abstract | Publisher Full Text | Free Full Text

50. Quinn KM, Zaloumis SG, Cukalac T, et al:: Heightened self-reactivity associated with selective survival, but not expansion, of naïve virus-specific $C D 8^{+} T$ cells in aged mice. Proc Natl Acad Sci U S A. 2016; 113(5): 1333-1338. PubMed Abstract | Publisher Full Text | Free Full Text

51. Mandl JN, Monteiro JP, Vrisekoop N, et al.: T cell-positive selection uses selfligand binding strength to optimize repertoire recognition of foreign antigens. Immunity. 2013; 38(2): 263-274.

PubMed Abstract | Publisher Full Text | Free Full Text

52. Fulton RB, Hamilton SE, Xing Y, et al:: The TCR's sensitivity to self peptide-MHC dictates the ability of naive $\mathrm{CDB}^{+} \mathrm{T}$ cells to respond to foreign antigens. Nat Immunol. 2015; 16(1): 107-117.

PubMed Abstract | Publisher Full Text | Free Full Text

53. Shechter R, Ziv Y, Schwartz M: New GABAergic interneurons supported by myelin-specific T cells are formed in intact adult spinal cord. Stem Cells. 2007 25(9): 2277-2282.

PubMed Abstract | Publisher Full Text

54. Ziv $Y$, Ron N, Butovsky O, et al.: Immune cells contribute to the maintenance of neurogenesis and spatial learning abilities in adulthood. Nat Neurosci. 2006; 9(2): 268-275.

PubMed Abstract | Publisher Full Text

55. Kipnis J, Gadani S, Derecki NC: Pro-cognitive properties of T cells. Nat Rev Immunol. 2012; 12(9): 663-669.

PubMed Abstract | Publisher Full Text | Free Full Text

56. Derecki NC, Cardani AN, Yang $\mathrm{CH}$, et al:: Regulation of learning and memory by meningeal immunity: a key role for IL-4. J Exp Med. 2010; 207(5): 1067-1080. PubMed Abstract | Publisher Full Text | Free Full Text

57. Baruch $\mathrm{K}$, Schwartz M: CNS-specific $\mathrm{T}$ cells shape brain function via the choroid plexus. Brain Behav Immun. 2013; 34: 11-16. PubMed Abstract | Publisher Full Text

58. Radjavi A, Smirnov I, Derecki N, et al.: Dynamics of the meningeal CD4+ T-cell repertoire are defined by the cervical lymph nodes and facilitate cognitive task performance in mice. Mol Psychiatry. 2014; 19(5): 531-533. PubMed Abstract | Publisher Full Text | Free Full Text

59. Cohen IR: The self, the world and autoimmunity. Sci Am. 1988; 258(4): 52-60. PubMed Abstract

60. Huttenlocher PR: Synaptic density in human frontal cortex - developmental changes and effects of aging. Brain Res. 1979; 163(2): 195-205. PubMed Abstract | Publisher Full Text

61. Petanjek Z, Judaš $M$, Šimic G, et al.: Extraordinary neoteny of synaptic spines in the human prefrontal cortex. Proc Natl Acad Sci U S A. 2011; 108(32): 13281-13286.

PubMed Abstract | Publisher Full Text | Free Full Text

62. Pakkenberg B, Gundersen HJ: Neocortical neuron number in humans: effect of sex and age. J Comp Neurol. 1997; 384(2): 312-320.

PubMed Abstract | Publisher Full Text

63. Yeung MS, Zdunek S, Bergmann O, et al.: Dynamics of Oligodendrocyte Generation and Myelination in the Human Brain. Cell. 2014; 159(4): 766-774 PubMed Abstract | Publisher Full Text

64. Frost JL, Schafer DP: Microglia: Architects of the Developing Nervous System Trends Cell Biol. 2016; 26(8): 587-597. PubMed Abstract | Publisher Full Text | Free Full Text

65. Matcovitch-Natan O, Winter DR, Giladi A, et al.: Microglia development follows a stepwise program to regulate brain homeostasis. Science. 2016; 353(6301): aad8670.

PubMed Abstract | Publisher Full Text

66. Xanthos DN, Sandkühler J: Neurogenic neuroinflammation: inflammatory CNS reactions in response to neuronal activity. Nat Rev Neurosci. 2014; 15(1): 43-53. PubMed Abstract | Publisher Full Tex

67. Beattie EC, Stellwagen D, Morishita W, et al.: Control of Synaptic Strength by Glial TNFalpha. Science. 2002; 295(5563): 2282-2285. PubMed Abstract | Publisher Full Text

68. Zhu PJ, Huang W, Kalikulov D, et al.: Suppression of PKR promotes network excitability and enhanced cognition by interferon- $\gamma$-mediated disinhibition. Cell. 2011; 147(6): 1384-1396.

PubMed Abstract | Publisher Full Text | Free Full Text

69. Filiano $\mathrm{AJ}, \mathrm{Xu} \mathrm{Y}$, Tustison $\mathrm{NJ}$, et al.: Unexpected role of interferon- $\gamma$ in regulating neuronal connectivity and social behaviour. Nature. 2016; 535(7612): 425-429. PubMed Abstract | Publisher Full Text | Free Full Text
70. Hines JH, Ravanelli AM, Schwindt R, et al.: Neuronal activity biases axon selection for myelination in vivo. Nat Neurosci. 2015; 18(5): 683-689. PubMed Abstract | Publisher Full Text | Free Full Text

71. Mensch S, Baraban M, Almeida R, et al:: Synaptic vesicle release regulates myelin sheath number of individual oligodendrocytes in vivo. Nat Neurosci. 2015; 18(5): 628-630.

PubMed Abstract | Publisher Full Text | Free Full Text

72. Scholz J, Klein MC, Behrens TE, et al:: Training induces changes in white-matter architecture. Nat Neurosci. 2009; 12(11): 1370-1371. PubMed Abstract | Publisher Full Text | Free Full Text

73. Klingberg T, Hedehus M, Temple E, et al:: Microstructure of temporo-parietal white matter as a basis for reading ability: evidence from diffusion tensor magnetic resonance imaging. Neuron. 2000; 25(2): 493-500. PubMed Abstract | Publisher Full Text

74. Zhu PJ, Huang W, Kalikulov D, et al:: Suppression of PKR Promotes Network Excitability and Enhanced Cognition by Interferon- $\gamma$-Mediated Disinhibition. Cell. 2011; 147(6): 1384-1396.

PubMed Abstract | Publisher Full Text | Free Full Text

75. Zhang X, Surguladze N, Slagle-Webb B, et al:: Cellular iron status influences the functional relationship between microglia and oligodendrocytes. Glia. 2006; 54(8): 795-804.

PubMed Abstract | Publisher Full Text

76. Miron VE, Boyd A, Zhao JW, et al:: M2 microglia and macrophages drive oligodendrocyte differentiation during CNS remyelination. Nat Neurosci. 2013; 16(9): 1211-1218

PubMed Abstract | Publisher Full Text | Free Full Text

77. Whitaker KJ, Vértes PE, Romero-Garcia R, et al.: Adolescence is associated with genomically patterned consolidation of the hubs of the human brain connectome. Proc Natl Acad Sci U S A. 2016; 113(32): 9105-9110. PubMed Abstract | Publisher Full Text | Free Full Text

78. Miller DJ, Duka T, Stimpson CD, et al:: Prolonged myelination in human neocortical evolution. Proc Natl Acad Sci U S A. 2012; 109(41): 16480-16485 PubMed Abstract | Publisher Full Text | Free Full Text

79. van de Leemput J, Boles NC, Kiehl TR, et al:: CORTECON: A Temporal Transcriptome Analysis of In Vitro Human Cerebral Cortex Development from Human Embryonic Stem Cells. Neuron. 2014; 83(1): 51-68. PubMed Abstract | Publisher Full Text

80. Louveau A, Smirnov I, Keyes TJ, et al:: Structural and functional features of central nervous system lymphatic vessels. Nature. 2015; 523(7560): 337-341. PubMed Abstract | Publisher Full Text | Free Full Text

81. Raper D, Louveau A, Kipnis J: How Do Meningeal Lymphatic Vessels Drain the CNS? Trends Neurosci. 2016; 39(9): 581-586.

PubMed Abstract | Publisher Full Text | Free Full Text

82. Fenalti G, Buckle AM: Structural biology of the GAD autoantigen. Autoimmun Rev. 2010; 9(3): 148-152.

PubMed Abstract | Publisher Full Text

83. Mende M, Fletcher EV, Belluardo JL, et al: Sensory-Derived Glutamate Regulates Presynaptic Inhibitory Terminals in Mouse Spinal Cord. Neuron. 2016; 90(6): 1189-1202.

PubMed Abstract | Publisher Full Text | Free Full Text

84. Zisimopoulou P, Brenner T, Trakas N, et al:: Serological diagnostics in myasthenia gravis based on novel assays and recently identified antigens. Autoimmun Rev. 2013; 12(9): 924-930.

PubMed Abstract | Publisher Full Tex

85. Sarter M, Parikh V, Howe WM: Phasic acetylcholine release and the volume transmission hypothesis: time to move on. Nat Rev Neurosci. 2009; 10(5): 383-390.

PubMed Abstract | Publisher Full Text | Free Full Text

86. Shoda H, Fujio K Sakurai K, et al: Autoantigen BiP-Derived HLA-DR4 Epitopes Differentially Recognized by Effector and Regulatory T Cells in Rheumatoid Arthritis. Arthritis Rheumatol. 2015; 67(5): 1171-1181. PubMed Abstract | Publisher Full Text

87. Yoo SA, You S, Yoon HJ, et al:: A novel pathogenic role of the ER chaperone GRP78/BiP in rheumatoid arthritis. $J$ Exp Med. 2012; 209(4): 871-886. PubMed Abstract | Publisher Full Text | Free Full Text

88. Fukata $\mathrm{Y}$, Tzingounis AV, Trinidad JC, et al:: Molecular constituents of neuronal AMPA receptors. J Cell Biol. 2005; 169(3): 399-404. PubMed Abstract | Publisher Full Text | Free Full Text

89. Cohen IR: Autoantibody repertoires, natural biomarkers, and system controllers. Trends Immunol. 2013; 34(12): 620-625. PubMed Abstract | Publisher Full Text

90. Willis D, Li KW, Zheng JQ, et al.: Differential transport and local translation of cytoskeletal, injury-response, and neurodegeneration protein mRNAs in axons. J Neurosci. 2005; 25(4): 778-791. PubMed Abstract | Publisher Full Text

91. Hansen JJ, Dürr A, Cournu-Rebeix I, et al:: Hereditary spastic paraplegia SPG13 is associated with a mutation in the gene encoding the mitochondrial chaperonin Hsp60. Am J Hum Genet. 2002; 70(5): 1328-32. PubMed Abstract | Publisher Full Text | Free Full Text

92. Wolin S: RNPs and autoimmunity: 20 years later. RNA. 2015; 21(4): 548-9. PubMed Abstract | Publisher Full Text | Free Full Text 
93. Bagni C, Greenough WT: From mRNP trafficking to spine dysmorphogenesis: the roots of fragile X syndrome. Nat Rev Neurosci. 2005; 6(5): 376-87. PubMed Abstract | Publisher Full Text

94. Nussbacher JK, Batra R, Lagier-Tourenne C, et al:: RNA-binding proteins in neurodegeneration: Seq and you shall receive. Trends Neurosci. 2015; 38(4): 226-36.

PubMed Abstract | Publisher Full Text | Free Full Text

95. Richter JD, Bassell GJ, Klann E: Dysregulation and restoration of translational homeostasis in fragile $X$ syndrome. Nat Rev Neurosci. 2015; 16(10): 595-605. PubMed Abstract | Publisher Full Text | Free Full Text

96. Liu-Yesucevitz L, Bassell GJ, Gitler AD, et al:: Local RNA translation at the synapse and in disease. $J$ Neurosci. 2011; 31(45): 16086-16093. PubMed Abstract | Publisher Full Text | Free Full Text

97. Stepniak B, Kästner A, Poggi G, et al:: Accumulated common variants in the broader fragile $\mathrm{X}$ gene family modulate autistic phenotypes. EMBO Mol Med. 2015; 7(12): 1565-1579.

PubMed Abstract | Publisher Full Text | Free Full Text

98. Berto S, Usui N, Konopka G, et al.: ELAVL2-regulated transcriptional and splicing networks in human neurons link neurodevelopment and autism. Hum Mol Genet. 2016; 25(12): 2451-2464.

PubMed Abstract | Publisher Full Text

99. Kwiatkowski TJ Jr, Bosco DA, Leclerc AL, et al:: Mutations in the FUS/TLS gene on chromosome 16 cause familial amyotrophic lateral sclerosis. Science. 2009; 323(5918): 1205-8.

PubMed Abstract | Publisher Full Text

100. Thomas M, Alegre-Abarrategui J, Wade-Martins R: RNA dysfunction and aggrephagy at the centre of an amyotrophic lateral sclerosis/frontotemporal dementia disease continuum. Brain. 2013; 136(Pt 5): 1345-1360. PubMed Abstract | Publisher Full Text

101. El Fatimy R, Davidovic L, Tremblay S, et al:: Tracking the Fragile X Mental Retardation Protein in a Highly Ordered Neuronal RiboNucleoParticles Population: A Link between Stalled Polyribosomes and RNA Granules. PLOS Genet. 2016; 12(7): e1006192.

PubMed Abstract | Publisher Full Text | Free Full Text

102. Yong J, Pellizzoni L, Dreyfuss G: Sequence-specific interaction of U1 snRNA with the SMN complex. EMBO J. 2002; 21(5): 1188-96. PubMed Abstract | Publisher Full Text | Free Full Text

103. Scheckel C, Drapeau E, Frias MA, et al:: Regulatory consequences of neuronal ELAV-like protein binding to coding and non-coding RNAs in human brain. eLife. 2016; 5: pii: e10421.

PubMed Abstract | Publisher Full Text | Free Full Text

104. Al Kindi MA, Colella AD, Chataway TK, et al:: Secreted autoantibody repertoires in Sjögren's syndrome and systemic lupus erythematosus: A proteomic approach. Autoimmun Rev. 2016; 15(4): 405-10. PubMed Abstract | Publisher Full Text

105. Stafford HA, Anderson CJ, Reichlin M: Unmasking of anti-ribosomal P autoantibodies in healthy individuals. J Immunol. 1995; 155(5): 2754-61. PubMed Abstract

106. Buxbaum AR, Wu B, Singer RH: Single $\beta$-actin mRNA detection in neurons reveals a mechanism for regulating its translatability. Science. 2014; 343(6169): 419-422.

PubMed Abstract | Publisher Full Text | Free Full Text

107. Graber TE, Hébert-Seropian S, Khoutorsky A, et al.: Reactivation of stalled polyribosomes in synaptic plasticity. Proc Natl Acad Sci U S A. 2013; 110(40): 16205-10.

PubMed Abstract | Publisher Full Text | Free Full Text

108. Greco A, Rizzo MI, De Virgilio A, et al.: Goodpasture's syndrome: a clinical update. Autoimmun Rev. 2015; 14(3): 246-253.

PubMed Abstract | Publisher Full Text

109. Foster MH: Basement membranes and autoimmune diseases. Matrix Biol. 2016 pii: S0945-053X(16)30147-0. PubMed Abstract | Publisher Full Text | Free Full Text

110. Barak $\mathrm{T}$, Kwan KY, Louvi $\mathrm{A}$, et al.: Recessive LAMC3 mutations cause malformations of occipital cortical development. Nat Genet. 2011; 43(6): 590-4. PubMed Abstract | Publisher Full Text | Free Full Text

111. Liu YB, Tewari A, Salameh J, et al:: A dystonia-like movement disorder with brain and spinal neuronal defects is caused by mutation of the mouse laminin B1 subunit, Lamb1. eLife. 2015; 4: pii: e11102. PubMed Abstract | Publisher Full Text | Free Full Text

112. Qin J, Liang J, Ding M: Perlecan antagonizes collagen IV and ADAMTS9/GON-1 in restricting the growth of presynaptic boutons. J Neurosci. 2014; 34(31): 10311-10324. PubMed Abstract | Publisher Full Text

113. Kurshan PT, Phan AQ, Wang GJ, et al:: Regulation of synaptic extracellula matrix composition is critical for proper synapse morphology. $J$ Neurosci. 2014; 34(38): 12678-89. PubMed Abstract | Publisher Full Text | Free Full Text

114. Spritz RA: Six decades of vitiligo genetics: genome-wide studies provide insights into autoimmune pathogenesis. J Invest Dermatol. 2012; 132(2): 268-273.

PubMed Abstract | Publisher Full Text | Free Full Text

115. Asanuma M, Miyazaki I, Diaz-Corrales FJ, et al.: Transplantation of melanocytes obtained from the skin ameliorates apomorphine-induced abnormal behavio in rodent hemi-parkinsonian models. PLoS One. 2013; 8(6): e65983. PubMed Abstract | Publisher Full Text | Free Full Text

116. Hearing VJ: Determination of melanin synthetic pathways. J Invest Dermatol. 2011; 131(E1): E8-E11.

PubMed Abstract | Publisher Full Text

117. Rahoma SF, Sandhu HK, McDonagh AJ, et al:: Epitopes, avidity and IgG subclasses of tyrosine hydroxylase autoantibodies in vitiligo and alopecia areata patients. Br J Dermatol. 2012; 167(1): 17-28.

PubMed Abstract | Publisher Full Text

118. Kemp EH, Emhemad S, Akhtar S, et al:: Autoantibodies against tyrosine hydroxylase in patients with non-segmental (generalised) vitiligo. Exp Dermatol 2011; 20(1): 35-40.

PubMed Abstract | Publisher Full Text

119. Kemp EH, Waterman EA, Hawes BE, et al:: The melanin-concentrating hormone receptor 1, a novel target of autoantibody responses in vitiligo. $J$ Clin Invest. 2002; 109(7): 923-30.

PubMed Abstract | Publisher Full Text | Free Full Text

120. Pissios $\mathrm{P}$ : Animals models of $\mathrm{MCH}$ function and what they can tell us about its role in energy balance. Peptides. 2009; 30(11): 2040-2044. PubMed Abstract | Publisher Full Text | Free Full Text

121. Torterolo $\mathrm{P}$, Scorza $\mathrm{C}$, Lagos $\mathrm{P}$, et al.: Melanin-Concentrating Hormone (MCH): Role in REM Sleep and Depression. Front Neurosci. 2015; 9: 475. PubMed Abstract | Publisher Full Text | Free Full Text

122. McLachlan SM, Rapoport B: Breaking tolerance to thyroid antigens: changing concepts in thyroid autoimmunity. Endocr Rev. 2014; 35(1): 59-105. PubMed Abstract | Publisher Full Text | Free Full Text

123. Blanchin S, Coffin C, Viader F, et al.: Anti-thyroperoxidase antibodies from patients with Hashimoto's encephalopathy bind to cerebellar astrocytes. J Neuroimmunol. 2007; 192(1-2): 13-20. PubMed Abstract | Publisher Full Text

124. Thrasyvoulides A, Sakarellos-Daitsiotis M, Philippou G, et al.: B-cell autoepitopes on the acetylcholinesterase-homologous region of human thyroglobulin: association with Graves' disease and thyroid eye disease. Eur J Endocrinol. 2001; 145(2): 119-127. PubMed Abstract | Publisher Full Text

125. Mappouras DG, Philippou G, Haralambous S, et al:: Antibodies to acetylcholinesterase cross-reacting with thyroglobulin in myasthenia gravis and Graves's disease. Clin Exp Immunol. 1995; 100(2): 336-343. PubMed Abstract | Publisher Full Text | Free Full Text

126. Ludgate $\mathrm{M}$, Dong $\mathrm{Q}$, Dreyfus $\mathrm{PA}$, et al:: Definition, at the molecular level, of a thyroglobulin-acetylcholinesterase shared epitope: study of its pathophysiological significance in patients with Graves' ophthalmopathy. Autoimmunity. 1989; 3(3): 167-176. PubMed Abstract | Publisher Full Text

127. Park YN, Arvan P: The acetylcholinesterase homology region is essential for normal conformational maturation and secretion of thyroglobulin. J Biol Chem. 2004; 279(17): 17085-17089. PubMed Abstract | Publisher Full Text

128. Lee J, Wang X, Di Jeso B, et al:: The cholinesterase-like domain, essential in thyroglobulin trafficking for thyroid hormone synthesis, is required for protein dimerization. J Biol Chem. 2009; 284(19): 12752-12761. PubMed Abstract | Publisher Full Text | Free Full Text

129. Massardo L, Bravo-Zehnder M, Calderón J, et al.: Anti- $N$-methyl-D-aspartate receptor and anti-ribosomal-P autoantibodies contribute to cognitive dysfunction in systemic lupus erythematosus. Lupus. 2015; 24(6): 558-568. PubMed Abstract | Publisher Full Text

130. Lauvsnes MB, Beyer MK, Kvaløy JT, et al.: Association of hippocampal atrophy with cerebrospinal fluid antibodies against the NR2 subtype of the $\mathrm{N}$-methylD-aspartate receptor in patients with systemic lupus erythematosus and patients with primary Sjögren's syndrome. Arthritis Rheumatol. 2014; 66(12): 3387-3394.

PubMed Abstract | Publisher Full Text

131. Bravo-Zehnder M, Toledo EM, Segovia-Miranda F, et al: Anti-ribosomal P protein autoantibodies from patients with neuropsychiatric lupus impair memory in mice. Arthritis Rheumatol. 2015; 67(1): 204-214. PubMed Abstract | Publisher Full Text

132. Le Guern V, Belin C, Henegar C, et al: Cognitive function and ${ }^{99 m} T c-E C D$ brain SPECT are significantly correlated in patients with primary Sjogren syndrome: a case-control study. Ann Rheum Dis. 2010; 69(1): 132-137. PubMed Abstract | Publisher Full Text

133. Blanc F, Longato N, Jung B, et al:: Cognitive Dysfunction and Dementia in Primary Sjögren's Syndrome. ISRN Neurol. 2013; 2013: 501327. PubMed Abstract | Publisher Full Text | Free Full Text

134. Segal BM, Rhodus N, Moser Sivils KL, et al.: Validation of the brief cognitive symptoms index in Sjögren syndrome. J Rheumatol. 2014; 41(10): 2027-33. PubMed Abstract | Publisher Full Text

135. Lauvsnes MB, Maroni SS, Appenzeller S, et al.: Memory dysfunction in primary Sjögren's syndrome is associated with anti-NR2 antibodies. Arthritis Rheum. 2013; 65(12): 3209-17. PubMed Abstract | Publisher Full Text

136. Laurent C, Capron J, Quillerou B, et al: Steroid-responsive encephalopathy associated with autoimmune thyroiditis (SREAT): Characteristics, treatment and outcome in $\mathbf{2 5 1}$ cases from the literature. Autoimmun Rev. 2016; 15(12): 
1129-1133.

PubMed Abstract | Publisher Full Text

137. Leyhe $\mathrm{T}$, Müssig $\mathrm{K}$ : Cognitive and affective dysfunctions in autoimmune thyroiditis. Brain Behav Immun. 2014; 41: 261-6. PubMed Abstract | Publisher Full Text

138. Pilhatsch M, Schlagenhauf $F$, Silverman $D$, et al.: Antibodies in autoimmune thyroiditis affect glucose metabolism of anterior cingulate. Brain Behav Immun. 2014; 37: 73-7.

PubMed Abstract | Publisher Full Text

139. Joaquim AF, Appenzeller S: Neuropsychiatric manifestations in rheumatoid arthritis. Autoimmun Rev. 2015; 14(12): 1116-22.

PubMed Abstract | Publisher Full Text

140. Hamed SA, Selim ZI, Elattar AM, et al.: Assessment of biocorrelates for brain involvement in female patients with rheumatoid arthritis. Clin Rheumatol. 2012; 31(1): 123-32.

PubMed Abstract | Publisher Full Text

141. Bartolini M, Candela M, Brugni M, et al.: Are behaviour and motor performances of rheumatoid arthritis patients influenced by subclinical cognitive impairments? A clinical and neuroimaging study. Clin Exp Rheumatol. 2002; 20(4): 491-7. PubMed Abstract

142. Sticherling M: Psoriasis and autoimmunity. Autoimmun Rev. 2016; 15(12): 1167-1170. PubMed Abstract | Publisher Full Text

143. Arakawa A, Siewert K, Stöhr J, et al:: Melanocyte antigen triggers autoimmunity in human psoriasis. J Exp Med. 2015; 212(13): 2203-12. PubMed Abstract | Publisher Full Text | Free Full Text

144. Schwartz J, Evers AW, Bundy C, et al.: Getting under the Skin: Report from the International Psoriasis Council Workshop on the Role of Stress in Psoriasis. Front Psychol. 2016; 7: 87.

PubMed Abstract | Publisher Full Text | Free Full Text

145. Colgecen E, Celikbilek A, Keskin DT: Cognitive Impairment in Patients with Psoriasis: A Cross-Sectional Study Using the Montreal Cognitive Assessment. Am J Clin Dermatol. 2016; 17(4): 413-9. PubMed Abstract | Publisher Full Text

146. Gisondi $P$, Sala F, Alessandrini F, et al.: Mild cognitive impairment in patients with moderate to severe chronic plaque psoriasis. Dermatology. 2014; 228(1): 78-85.

PubMed Abstract | Publisher Full Text

147. Bonneau J, Dumestre-Perard C, Rinaudo-Gaujous M, et al.: Systematic review: new serological markers (anti-glycan, anti-GP2, anti-GM-CSF Ab) in the prediction of IBD patient outcomes. Autoimmun Rev. 2015; 14(3): 231-45. PubMed Abstract | Publisher Full Text

148. Scott H, Panin VM: The role of protein $\mathbf{N}$-glycosylation in neural transmission. Glycobiology. 2014; 24(5): 407-17.

PubMed Abstract | Publisher Full Text | Free Full Text

149. Fang $P$, Wang $X J$, Xue $Y$, et al:: In-depth mapping of the mouse brain $\mathrm{N}$ glycoproteome reveals widespread $\mathrm{N}$-glycosylation of diverse brain proteins. Oncotarget. 2016; 7(5): 38796-38809.

PubMed Abstract | Publisher Full Text | Free Full Text

150. Nair VA, Beniwal-Patel P, Mbah I, et al.: Structural Imaging Changes and Behavioral Correlates in Patients with Crohn's Disease in Remission. Front Hum Neurosci. 2016; 10: 460. PubMed Abstract | Publisher Full Text | Free Full Text

151. Thomann AK, Thomann PA, Wolf RC, et al:: Altered Markers of Brain Development in Crohn's Disease with Extraintestinal Manifestations - A Pilot Study. PLoS One. 2016; 11(9): e0163202. PubMed Abstract | Publisher Full Text | Free Full Text

152. Kaushansky N, Eisenstein M, Zilkha-Falb R, et al:: The myelin-associated oligodendrocytic basic protein (MOBP) as a relevant primary target autoantigen in multiple sclerosis. Autoimmun Rev. 2010; 9(4): 233-236. PubMed Abstract | Publisher Full Text

153. Crisp SJ, Kullmann DM, Vincent A: Autoimmune synaptopathies. Nat Rev Neurosci. 2016; 17(2): 103-17. PubMed Abstract | Publisher Full Text

154. Ariño H, Höftberger R, Gresa-Arribas N, et al:: Paraneoplastic Neurological Syndromes and Glutamic Acid Decarboxylase Antibodies. JAMA Neurol. 2015; 72(8): 874-81.

PubMed Abstract | Publisher Full Text | Free Full Text

155. Dalmau J, Tüzün E, Wu H, et al:: Paraneoplastic anti-N-methyl-D-aspartate receptor encephalitis associated with ovarian teratoma. Ann Neurol. 2007; 61(1): 25-36.

PubMed Abstract | Publisher Full Text | Free Full Text

156. Lai M, Hughes EG, Peng $X$, et al:: AMPA receptor antibodies in limbic encephalitis alter synaptic receptor location. Ann Neurol. 2009; 65(4): 424-434. PubMled Abstract | Publisher Full Text | Free Full Text

157. Lancaster E, Huijbers MG, Bar V, et al:: Investigations of caspr2, an autoantigen of encephalitis and neuromyotonia. Ann Neurol. 2011; 69(2): 303-11. PubMed Abstract | Publisher Full Text | Free Full Text

158. Lai M, Huijbers MG, Lancaster E, et al:: Investigation of LGI1 as the antigen in limbic encephalitis previously attributed to potassium channels: a case series. Lancet Neurol. 2010; 9(8): 776-785.

PubMed Abstract | Publisher Full Text | Free Full Text

159. Lancaster E, Lai M, Peng $\mathrm{X}$, et al:: Antibodies to the $\mathrm{GABA}_{\mathrm{B}}$ receptor in limbic encephalitis with seizures: case series and characterisation of the antigen. Lancet Neurol. 2010; 9(1): 67-76.

PubMed Abstract | Publisher Full Text | Free Full Text

160. Petit-Pedrol $M$, Armangue $T$, Peng $X$, et al.: Encephalitis with refractory seizures, status epilepticus, and antibodies to the $\mathrm{GABA}_{\mathrm{A}}$ receptor: a case series, characterisation of the antigen, and analysis of the effects of antibodies. Lancet Neurol. 2014; 13(3): 276-86.

PubMed Abstract | Publisher Full Text | Free Full Text

161. Lancaster E, Martinez-Hernandez E, Titulaer MJ, et al:: Antibodies to metabotropic glutamate receptor 5 in the Ophelia syndrome. Neurology. 2011 77(18): 1698-1701.

PubMed Abstract | Publisher Full Text | Free Full Text

162. Hutchinson $M$, Waters $P, M c H u g h ~ J$, et al:: Progressive encephalomyelitis, rigidity, and myoclonus: a novel glycine receptor antibody. Neurology. 2008; 71(16): 1291-1292.

PubMed Abstract | Publisher Full Text

163. Gresa-Arribas N, Planagumà J, Petit-Pedrol M, et al:: Human neurexin-3 antibodies associate with encephalitis and alter synapse development Neurology. 2016; 86(24): 2235-2242. PubMed Abstract | Publisher Full Text | Free Full Text

164. Werner C, Pauli M, Doose S, et al.: Human autoantibodies to amphiphysin induce defective presynaptic vesicle dynamics and composition. Brain. 2016; 139(Pt 2): 365-379.

PubMed Abstract | Publisher Full Text

165. Schwartz M, Cohen IR: Autoimmunity can benefit self-maintenance. Immunol Today. 2000; 21(6): 265-8. PubMed Abstract | Publisher Full Text

166. Kearney JF, Patel P, Stefanov EK, et al:: Natural antibody repertoires: development and functional role in inhibiting allergic airway disease. Annu Rev Immunol. 2015; 33: 475-504.

PubMed Abstract | Publisher Full Text

167. Belkaid $\mathrm{Y}$, Hand TW: Role of the microbiota in immunity and inflammation. Cell. 2014; 157(1): 121-141.

PubMed Abstract | Publisher Full Text | Free Full Text

168. Hooper LV, Littman DR, Macpherson AJ: Interactions between the microbiota and the immune system. Science. 2012; 336(6086): 1268-1273.

PubMed Abstract | Publisher Full Text | Free Full Text

169. Eberl G: Immunity by equilibrium. Nat Rev Immunol. 2016; 16(8): 524-532. PubMed Abstract | Publisher Full Text

170. Scharschmidt TC, Vasquez KS, Truong HA, et al.: A Wave of Regulatory T Cells into Neonatal Skin Mediates Tolerance to Commensal Microbes. Immunity. 2015; 43(5): 1011-1021.

PubMed Abstract | Publisher Full Text | Free Full Text

171. Cebula A, Seweryn M, Rempala GA, et al:: Thymus-derived regulatory T cells contribute to tolerance to commensal microbiota. Nature. 2013; 497(7448): 258-262.

PubMed Abstract | Publisher Full Text | Free Full Text

172. Lathrop SK, Bloom SM, Rao SM, et al:: Peripheral education of the immune system by colonic commensal microbiota. Nature. 2011; 478(7368): 250-254. PubMed Abstract | Publisher Full Text | Free Full Text

173. Atarashi $\mathrm{K}$, Tanoue $\mathrm{T}$, Shima $\mathrm{T}$, et al.: Induction of colonic regulatory $\mathrm{T}$ cells by indigenous Clostridium species. Science. 2011; 331(6015): 337-341. PubMed Abstract | Publisher Full Text | Free Full Text

174. Round JL, Mazmanian SK: Inducible Foxp3 $3^{+}$regulatory T-cell development by a commensal bacterium of the intestinal microbiota. Proc Natl Acad Sci U S A. 2010; 107(27): 12204-12209.

PubMed Abstract | Publisher Full Text | Free Full Text

175. Brooks AW, Kohl KD, Brucker RM, et al:: Phylosymbiosis: Relationships and Functional Effects of Microbial Communities across Host Evolutionary History. PLOS Biol. 2016; 14(11): e2000225.

PubMed Abstract | Publisher Full Text | Free Full Text

176. Hansen JJ, Dürr A, Cournu-Rebeix I, et al:: Hereditary spastic paraplegia SPG13 is associated with a mutation in the gene encoding the mitochondrial chaperonin Hsp60. Am J Hum Genet. 2002; 70(5): 1328-1332. PubMed Abstract | Publisher Full Text | Free Full Text

177. Kneussel M, Wagner W: Myosin motors at neuronal synapses: drivers of membrane transport and actin dynamics. Nat Rev Neurosci. 2013; 14(4): 233-247. PubMed Abstract | Publisher Full Text

178. Miki T, Malagon G, Pulido C, et al.: Actin- and Myosin-Dependent Vesicle Loading of Presynaptic Docking Sites Prior to Exocytosis. Neuron. 2016; 91(4): 808-823.

PubMed Abstract | Publisher Full Text

179. Winden KD, Oldham MC, Mirnics K, et al.: The organization of the transcriptional network in specific neuronal classes. Mol Syst Biol. 2009; 5: 291. PubMed Abstract | Publisher Full Text | Free Full Text

180. Park JW, Voss PG, Grabski S, et al:: Association of galectin-1 and galectin-3 with Gemin 4 in complexes containing the SMN protein. Nucleic Acids Res. 2001; 29(17): 3595-3602. PubMed Abstract | Free Full Text

181. Huh GS, Boulanger LM, Du H, et al.: Functional requirement for class I MHC in CNS development and plasticity. Science. 2000; 290(5499): 2155-9. PubMed Abstract | Publisher Full Text | Free Full Text

182. den Braber I, Mugwagwa T, Vrisekoop N, et al.: Maintenance of peripheral naive 
T cells is sustained by thymus output in mice but not humans. Immunity. 2012; 36(2): 288-297.

PubMed Abstract | Publisher Full Text

183. Hochweller K, Wabnitz GH, Samstag Y, et al:: Dendritic cells control T cell tonic signaling required for responsiveness to foreign antigen. Proc Natl Acad Sci US A. 2010; 107(13): 5931-6.

PubMed Abstract | Publisher Full Text | Free Full Text

184. Ernst B, Lee DS, Chang JM, et al:: The peptide ligands mediating positive selection in the thymus control T cell survival and homeostatic proliferation in the periphery. Immunity. 1999; 11(2): 173-81. PubMed Abstract | Publisher Full Text

185. Nikolich-Zugich J, Slifka MK, Messaoudi I: The many important facets of T-cell repertoire diversity. Nat Rev Immunol. 2004; 4(2): 123-32. PubMed Abstract | Publisher Full Text

186. Castillo-Gómez E, Oliveira B, Tapken $\mathrm{D}$, et al:: All naturally occurring autoantibodies against the NMDA receptor subunit NR1 have pathogenic potential irrespective of epitope and immunoglobulin class. Mol Psychiatry. 2016. PubMed Abstract | Publisher Full Text

187. Hammer C, Stepniak B, Schneider A, et al:: Neuropsychiatric disease relevance of circulating anti-NMDA receptor autoantibodies depends on blood-brain barrier integrity. Mol Psychiatry. 2014; 19(10): 1143-9. PubMed Abstract | Publisher Full Text

188. Schwartz M, Kipnis J, Rivest S, et al:: How do immune cells support and shape the brain in health, disease, and aging? J Neurosci. 2013; 33(45): 17587-96.

PubMed Abstract | Publisher Full Text | Free Full Text

189. Rowley B, Tang L, Shinton S, et al:: Autoreactive B-1 B cells: constraints on natural autoantibody B cell antigen receptors. J Autoimmun. 2007; 29(4): 236-245.

PubMed Abstract | Publisher Full Text | Free Full Text

190. Julien S, Soulas P, Garaud JC, et al:: B cell positive selection by soluble selfantigen. J Immunol. 2002; 169(8): 4198-204. PubMed Abstract | Publisher Full Text

191. Titman $P$, Pink E, Skucek E, et al.: Cognitive and behavioral abnormalities in children after hematopoietic stem cell transplantation for severe congenita immunodeficiencies. Blood. 2008; 112(9): 3907-13. PubMed Abstract | Publisher Full Text

192. Vorstman JA, Breetvelt EJ, Duijff SN, et al:: Cognitive decline preceding the onset of psychosis in patients with 22q11.2 deletion syndrome. JAMA Psychiatry. 2015; 72(4): 377-85. PubMed Abstract | Publisher Full Text | Free Full Text

193. Schneider M, Debbané M, Bassett AS, et al:: Psychiatric disorders from childhood to adulthood in 22q11.2 deletion syndrome: results from the International Consortium on Brain and Behavior in 22q11.2 Deletion
Syndrome. Am J Psychiatry. 2014; 171(6): 627-639. PubMled Abstract | Publisher Full Text | Free Full Text

194. Chen SJ, Chao YL, Chen CY, et al: Prevalence of autoimmune diseases in in-patients with schizophrenia: nationwide population-based study. $\mathrm{Br} J$ Psychiatry. 2012; 200(5): 374-80. PubMed Abstract | Publisher Full Text

195. Bergink V, Gibney SM, Drexhage HA: Autoimmunity, inflammation, and psychosis: a search for peripheral markers. Biol Psychiatry. 2014; 75(4): 324-31. PubMed Abstract | Publisher Full Text

196. Sperner-Unterweger B, Fuchs D: Schizophrenia and psychoneuroimmunology: an integrative view. Curr Opin Psychiatry. 2015; 28(3): 201-6. PubMed Abstract | Publisher Full Text

197. Matelski L, Van de Water J: Risk factors in autism: Thinking outside the brain. J Autoimmun. 2016; 67: 1-7. PubMed Abstract | Publisher Full Text

198. Crespi BJ, Thiselton DL: Comparative immunogenetics of autism and schizophrenia. Genes Brain Behav. 2011; 10(7): 689-701. PubMed Abstract | Publisher Full Text

199. Moises HW, Yang L, Kristbjarnarson $\mathrm{H}$, et al.: An international two-stage genomewide search for schizophrenia susceptibility genes. Nat Genet. 1995; 11(3): 321-4. PubMed Abstract | Publisher Full Text

200. Corvin A, Morris DW: Genome-wide association studies: findings at the major histocompatibility complex locus in psychosis. Biol Psychiatry. 2014; 75(4): 276-83. PubMed Abstract | Publisher Full Text

201. Srinivasan S, Bettella F, Mattingsdal M, et al.: Genetic Markers of Human Evolution Are Enriched in Schizophrenia. Biol Psychiatry. 2016; 80(4): 284-292. PubMed Abstract | Publisher Full Text

202. Padgett DA, Glaser R: How stress influences the immune response. Trends Immunol. 2003; 24(8): 444-8.

PubMed Abstract | Publisher Full Text

203. Irwin MR, Cole SW: Reciprocal regulation of the neural and innate immune systems. Nat Rev Immunol. 2011; 11(9): 625-632. PubMed Abstract | Publisher Full Text | Free Full Text

204. Ben-Shaanan TL, Azulay-Debby H, Dubovik T, et al:: Activation of the reward system boosts innate and adaptive immunity. Nat Med. 2016; 22(8): 940-944. PubMed Abstract | Publisher Full Text

205. Cohen IR: Real and artificial immune systems: computing the state of the body. Nat Rev Immunol. 2007; 7(7): 569-74. PubMed Abstract | Publisher Full Text

206. Ben-Shaanan T, Schiller M, Rolls A: Studying brain-regulation of immunity with optogenetics and chemogenetics; A new experimental platform. Brain Behav Immun. 2016; pii: S0889-1591(16)30526-8. PubMed Abstract | Publisher Full Text 


\section{Open Peer Review}

\section{Current Peer Review Status:}

\section{Version 1}

Reviewer Report 09 May 2017

https://doi.org/10.5256/f1000research.11803.r22275

(C) 2017 Guaza C. This is an open access peer review report distributed under the terms of the Creative Commons Attribution License, which permits unrestricted use, distribution, and reproduction in any medium, provided the original work is properly cited.

\section{Carmen Guaza}

Functional and Systems Neurobiology Department, Neuroimmunology Group, Cajal Institute, CSIC, Madrid, Spain

Nataf presents a sound and provocative opinion piece. The article gets readers to open their mind about the view that superautoantigens are shaped by physiological events associated with brain development and function, all in an integrative view. It is amazing the model of co-evolution of the immune and nervous system exposed in a brilliant and coherent way to promote open discussion that will better the field and impact clinical approaches.

Is the topic of the opinion article discussed accurately in the context of the current literature?

Yes

Are all factual statements correct and adequately supported by citations?

Yes

Are arguments sufficiently supported by evidence from the published literature? Yes

Are the conclusions drawn balanced and justified on the basis of the presented arguments? Yes

Competing Interests: No competing interests were disclosed.

Reviewer Expertise: Neuroimmunology/neurosciences

I confirm that I have read this submission and believe that I have an appropriate level of expertise to confirm that it is of an acceptable scientific standard. 
Reviewer Report 03 May 2017

https://doi.org/10.5256/f1000research.11803.r22001

(C) 2017 Saoudi A. This is an open access peer review report distributed under the terms of the Creative Commons Attribution License, which permits unrestricted use, distribution, and reproduction in any medium, provided the original work is properly cited.

\begin{abstract}
Abdelhadi Saoudi
U1043, INSERM (French Institute of Health and Medical Research), Toulouse, France

This excellent opinion article by Serge Nataf is based on critical analysis of unrelated literature and proposes a sound model that bridge natural autoimmunity with brain development and functions. This model also raises several interesting biological questions (evolution, physiology and physiopathology) that will need the development of new experimental setting to understand the coevolution of the immune system and CNS.

Is the topic of the opinion article discussed accurately in the context of the current literature?

Yes
\end{abstract}

Are all factual statements correct and adequately supported by citations? Yes

Are arguments sufficiently supported by evidence from the published literature? Yes

Are the conclusions drawn balanced and justified on the basis of the presented arguments? Yes

Competing Interests: No competing interests were disclosed.

I confirm that I have read this submission and believe that I have an appropriate level of expertise to confirm that it is of an acceptable scientific standard.

Reviewer Report 22 February 2017

https://doi.org/10.5256/f1000research.11803.r20397

(C) 2017 Cohen I. This is an open access peer review report distributed under the terms of the Creative Commons Attribution License, which permits unrestricted use, distribution, and reproduction in any medium, provided the original work is properly cited.

Irun R. Cohen

Department of Immunology, Weizmann Institute of Science, Rehovot, Israel 
This Opinion Article by Serge Nataf is a brilliant synthesis; it integrates seemingly unrelated observations to build a coherent model that explains unsung relationships between natural "homuncular" autoimmunity and nervous system development. Nataf's model of the co-evolution of the immune and nervous systems is seminal biological thinking that bridges evolution, physiology, clinical medicine, health and disease. Readers will respond with challenges, experimental tests, and new understanding.

Is the topic of the opinion article discussed accurately in the context of the current literature?

Yes

Are all factual statements correct and adequately supported by citations? Yes

Are arguments sufficiently supported by evidence from the published literature? Yes

Are the conclusions drawn balanced and justified on the basis of the presented arguments? Yes

Competing Interests: No competing interests were disclosed.

I confirm that I have read this submission and believe that I have an appropriate level of expertise to confirm that it is of an acceptable scientific standard.

The benefits of publishing with F1000Research:

- Your article is published within days, with no editorial bias

- You can publish traditional articles, null/negative results, case reports, data notes and more

- The peer review process is transparent and collaborative

- Your article is indexed in PubMed after passing peer review

- Dedicated customer support at every stage

For pre-submission enquiries, contact research@f1000.com 